\title{
Natural and human controls on dune vegetation cover and disturbance
}

\section{Abstract}

8 Beaches and dunes are one of the most heavily used environments on Earth, with tourism

9 and residential uses leading to ecosystem loss and dune degradation. Many coastal dune fields also host a range of economic activities such as farming, mining, and animal grazing,

11 which can affect their evolution. The second half of the 20th century has seen an increase of dune vegetation cover in many dunes around the world, with climatic forcing often cited as a driver for this. However, identification of the relative contributions to landscape change variables driving disturbance and the likely landscape trajectory if the driver is removed. The
Irene Delgado-Fernandez ${ }^{1 *}$, Nicholas O'Keeffe ${ }^{1}$, Robin Davidson-Arnott ${ }^{2}$

${ }^{1}$ Geography Department, Edge Hill University, Ormskirk, Lancashire, UK

${ }^{2}$ Geography Department, University of Guelph, Ontario, Canada

*Corresponding author email: delgadoi@edgehill.ac.uk due to climate vs. natural and/or artificial disturbances remains unclear. This poses a problem for managers seeking to maintain some 'desirable' landscape characteristics, because understanding the reasons for dune field change is essential prior to implementing interventions, as is differentiating what is natural from what is not. This study proposes a systematic approach to identifying dune disturbances and isolating them from the effect of climate. The approach assumes that it is possible to measure dune disturbances by comparing observed vegetation cover with that expected due to climate. A semiquantitative procedure is proposed to explore the existence of disturbance, its significance, and the causes for it. The procedure can also be used in reverse to explore the effect of approach is tested with a case study of the Sefton dunes in NW England, a large dune field 
subject to multiple interventions and degrees of human impact. The discussion focuses on the importance of disturbance location and the range of variables involved in changes to vegetation cover at this and other locations. In natural dune fields, it is recommended as best practice to managers that artificial stressors and human-led disturbances are minimized to allow coastal dune systems to evolve naturally.

\section{Keywords}

31 Coastal dune field evolution, climate change, human impact, dune management.

\section{INTRODUCTION}

34 Coastal dunes are depositional features that depend on sediment input from the beach, wind events capable of transporting sediment, and the growing capacity of vegetation (Psuty, 1988; Delgado-Fernandez and Davidson-Arnott, 2011; Carter et al., 2018). Dunes are geographically diverse, with climatic variables such as precipitation, temperature, and wind patterns dictating their relative degree of mobility (Lancaster and Helm, 2000). The lack of vegetation in arid to semi-arid locations leads to coastal dunes that have larger degrees of mobility; wet conditions in tropical and temperate latitudes favour vegetation colonization and dune stabilization (Hesp, 2013). The long-term state of dune fields based on climatic conditions can be generally predicted using relatively simple mobility indices based on wind power (Tsoar, 2005) or on some combination between wind strength, precipitation, and

44 temperature (e.g., Lancaster and Helm, 2000).

47 including South Africa (e.g., Avis, 1989), Canada (e.g., Darke et al., 2013), Brazil (e.g., Seelinger et al., 2000), and several dune systems in West/Northwest Europe (Rhind et al., 
2001; Provoost et al., 2011). A mix of natural and anthropogenic processes have been cited as potential drivers for vegetation cover changes. These include alterations in the length of

51 the growing season (Jackson and Cooper, 2011), fluctuations in Pacific Decadal Oscillations (PDO) and El Niño-like events (Miot da Silva et al., 2013), management plans promoting dune stabilization such as planting and fencing (e.g., Arens et al., 2013; Pye et al., 2014), the spread of invasive species and/or eutrophication due to atmospheric nitrogen deposition (Provoost et al., 2011). However, the relative contribution of natural vs. human-induced disturbances has not been quantified, making it difficult to separate what is expected from climate variability and/or climate change from direct human impacts. Appropriate identification of artificial disturbances is important to detect whether the environment is in fact degraded or not (e.g., Nordstrom et al., 2000). If artificial disturbances are detected, then removing stressors and reasons for degradation can give the system an opportunity to recover autonomously, with some authors arguing that this is in fact the best management option for restoration (Elliot et al., 2007). This is particularly important in dune systems with moderate to large degrees of human impact such as NW Europe, where "restoring natural dune characteristics" should involve understanding of vegetation responses to climate, natural and anthropogenic disturbances, and dune evolutionary cycles (Hesp, 2013).

This study proposes a systematic approach that allows: (1) calculating the mobility state and estimating the amount of vegetation cover that can be expected due to climate; (2) distinguishing between natural and human causes/controls on vegetation cover and dune disturbance; (3) predicting the likely trajectory of a dune system if human impacts on

71 vegetation cover are reduced. This is important in order to identify any significant deviation 72 of a dune system from its predicted mean state, as well as to assess management 
73 interventions designed to either reduce or increase vegetation disturbance. The paper first

74 introduces the conceptual background for the approach (section 2) and describes its

75 application (section 3). The approach is then tested using the Sefton dunes (NW England) as

76 a case study. The Sefton coast benefits from rich data sets including changes in bare sand

77 and climate variables over 70 years and anthropogenic activities leading to a range of

78 disturbances. The discussion focuses on the role played by extent and location when

79 assessing the significance of disturbances to coastal dunes, as well as the capacity of the

80 landscape to recover following disturbances. Results presented in this article also provide

81 insights into the potential reasons for observed large scale (planetary) trends in dune

82 stabilization.

83

84

2 CONCEPTUAL BACKGROUND

\subsection{Establishing the general context for dune mobility and vegetation cover}

86 The climate of a region, and specifically rainfall amounts and annual distribution, exert a

87 primary control on dune vegetation growth (Hesp, 2002), which in turns controls dune

88 mobility (e.g., Arens et al., 2013; Pye et al., 2014;). Several authors have developed dune

89 mobility indices based on average wind strength and precipitation (e.g., Ash and Wasson,

90 1983; Lancaster, 1988) or wind power and drift potentials (Tsoar, 2005). Vegetation cover

91 also responds to climate variability leading, in turn, to cycles of dune activity (Hugenholtz

92 and Wolfe, 2005; Yizhaq et al., 2008). Most mobility indices have been developed for

93 continental dunes. However, coastal dune fields (just like their continental counterparts) are

94 affected by their regional climate, which is a main driver for the growth of vegetation

95 (Jackson and Cooper, 2011; Miot da Silva et al., 2013). Although further research is needed

96 on the application of mobility indices to coastal zones (see section 7.1), it is possible to use 
some dune mobility functions to understand climatic controls on coastal dune field developed by Lancaster (1988) was adopted here as a starting point due to its simplicity and easy application:

101

$$
M=\frac{W}{P / P E}
$$

where $\mathrm{W}$ is the annual percentage of the time the wind is above the threshold for sand using the method developed by Thorntwaite and Mather (TM; 1957). The TM method uses mean monthly temperatures and accounts for latitudinal differences in sunshine to

107 calculate PE. Once the $\mathrm{M}$ index has been calculated the expected mobility state of a dune field can be estimated using Table 1.

109

Table 1. Critical values for $M$ and qualitative category descriptors developed by Lancaster (1988).

\begin{tabular}{ll}
\hline M values & Qualitative category \\
\hline$>200$ & Fully active dunes \\
\hline $100-200$ & Mostly active but with vegetated interdunes and lower slopes \\
\hline $50-100$ & Mostly vegetated but with active dune crests \\
\hline$<50$ & Fully inactive dunes
\end{tabular}

112 The use of $\mathrm{M}$ in general, is not without limitations. Lancaster (1888) originally developed the

113 index for desert dunes and hence descriptors in Table 1 are associated with limited

114 vegetation compared to many coastal dunes. The index is sensitive to wind thresholds and 
115 does not perform well at a yearly scale (Lancaster and Helm, 2000). M can over- or under-

116 estimate mobility due to complex landscape dynamics including lag response times,

117 morphological resistance, elasticity variability leading to different stabilization rates, and the

118 hysteretic behaviour of dune mobility (Hugenholtz and Wolfe, 2005; Yizhaq et al., 2009).

119 However, the aim here is not to use $M$ as a precise predictor of actual dune state, but to 120 provide a broad climatic context for different dune fields. This helps informing qualitative

121 estimations of the relative amount of vegetation cover that could be expected because of 122 climate (V). We use $M$ to provide valuable information on the combined effect of $T$, $P$, and

123 W at a regional level and over time, and whether categorical changes to dune mobility

124 should be expected or not. M provides good estimations of long-term dune mobility at

125 timescales of decades (Lancaster and Helm, 2000) and responds well to natural oscillations

126 in climatic variables or even climate change (Muhs and Maatt, 1993). The index is also

127 capable of accounting for the impact of aridity and droughts (Wolfe, 1997) and episodic and

128 temporally variable wind activity (Bullard et al., 1997).

129

$130 \quad 2.2$ Estimating disturbance

131 Dune vegetation is sensitive to drivers not included in $M$ and can be disturbed both because

132 of natural processes and anthropogenic activities (e.g., Hesp and Martínez, 2007;

133 Hernández-Cordero et al., 2017). Disturbance (D) is therefore understood here as changes

134 to vegetation cover not explained because of climate, and its magnitude can be calculated 135 as: 
139 where $V_{o}$ is the observed vegetation cover and $V$ is that expected due to climate. When

140 observed vegetation is close to that expected disturbance is small. Medium to large

141 magnitude disturbances increase the percent of bare sand $(D>0)$ or the percent of

142 vegetation cover $(D<0)$ and have the potential to change mobility levels. The magnitude of

143 disturbance is sensitive to the size of the dune area under consideration. Therefore, the

144 significance of a particular disturbance is a combination between its magnitude and extent

145 (Table 2). For example, large storm surges eroding kilometres of coastal dunes can

146 significantly affect the percent of dune vegetation cover ( $D+$, large scale), vs. a walking trail

147 used by small numbers of people with little significance for overall vegetation cover (D+,

148 small scale). Management interventions leading to large magnitude, but localised

149 disturbances may score low to moderate significance in Table 2. These include, for example,

150 planting with vegetation areas of dune fields that are naturally mobile (D -) resulting in

151 increases in vegetation cover that are not expected due to climate, or creating artificial

152 notches and removing vegetation in naturally vegetated dune fields $(D+)$. A third element

153 should be included in analyses of cases such as these: disturbance location. The relevance of

154 this in the context of coastal dunes is discussed in section 7.2.

155

156

Table 2. Matrix to characterise observed disturbance or to estimate the degree of disturbance expected from

157 different drivers in table 3. Disturbance levels range from low (green) to moderate (yellow) and high (red). The

158 table should be combined with an assessment of the disturbance location.

159

Disturbance Significance

\begin{tabular}{llll} 
Disturbance Significance & & \\
\cline { 3 - 3 } & & Limited & Medium \\
\hline Magnitude & Small & & \\
\hline
\end{tabular}




\begin{tabular}{l} 
Moderate \\
\hline Large
\end{tabular}

\subsection{Identifying causes of disturbance}

162 Table 3 includes natural and human drivers of disturbance and controls on vegetation cover,

163 both specific to coastal dunes (e.g., littoral sediment budgets or changes in sea level) and

164 common to dunes elsewhere (e.g., grazing or farming). Table 3 is not an exhaustive list and

165 it does not consider all variables cited in the literature, such as changes to ground water

166 levels or nutrient excess (e.g., Arens et al., 2013), which could be added in future studies.

167 Instead, the objective here is to propose a technique to examine reasons for disturbance

168 and to indicate the trajectory one might expect if disturbances are reduced. cover and their relationship with disturbance magnitude (D).

\begin{tabular}{|c|c|c|c|c|}
\hline & & \\
\hline & & $\uparrow$ bare sand & Driver & $\uparrow$ vegetation cover \\
\hline \multirow{7}{*}{ 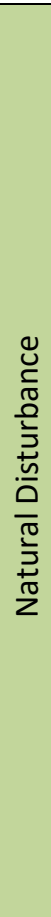 } & \multirow{4}{*}{ Geomorphology } & negative & littoral sediment budget & positive \\
\hline & & $\begin{array}{l}\text { negative (extreme } \\
\text { positive) }\end{array}$ & foredune sediment budget & positive \\
\hline & & rising & sea level & stable - falling? \\
\hline & & frequent & storm surges & infrequent \\
\hline & \multirow{3}{*}{ Vegetation } & $\begin{array}{l}\text { no burial/salt } \\
\text { tolerant }\end{array}$ & pioneer grasses & burial/salt tolerant \\
\hline & & $\begin{array}{l}\text { few to no salt } \\
\text { tolerant }\end{array}$ & shrubs & burial/salt tolerant \\
\hline & & grazers \& burrowers & animals & $\begin{array}{r}\text { few/no grazers } \\
\& \text { burrowers }\end{array}$ \\
\hline
\end{tabular}




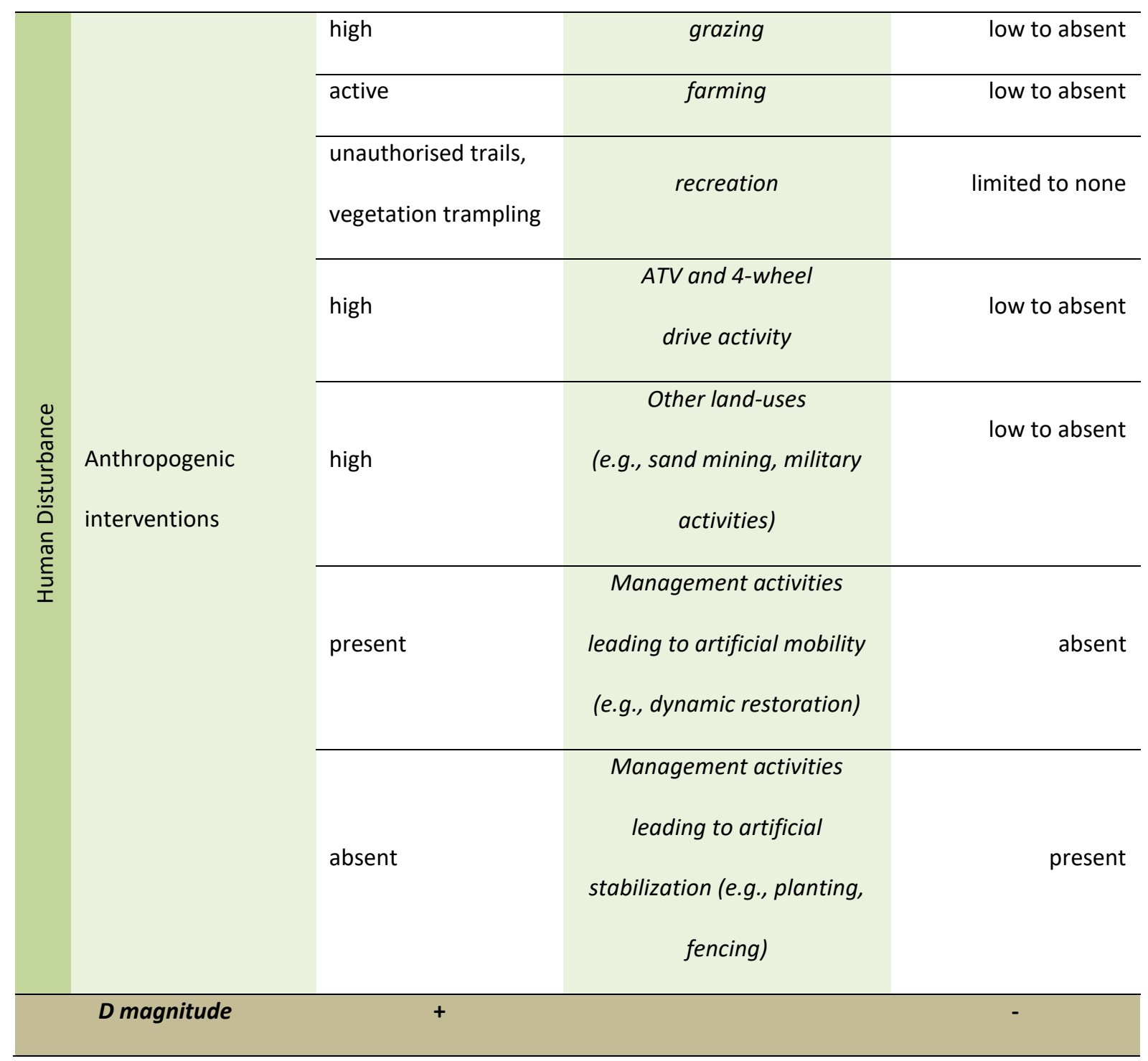

174 Natural disturbances such as changes to coastal sediment budgets or variability of some

175 animal populations (e.g., grazers and burrowers like rabbits) can change the proportion of

176 vegetation cover and affect dune mobility. Some of these natural disturbances can be linked

177 to human activities (e.g., human-induced rising sea-levels, or negative littoral budgets

178 generated because infrastructure updrift interferes with longshore currents and sediment

179 delivery to beaches downstream). However, Table 3 separates these from direct

180 anthropogenic interventions in the landscape, which helps in identifying changes to

181 vegetation cover due to land use and management. Most drivers have the potential of 
182

183

184

185

186

187

188

189

190

191

192

193

194

195

196

197

198

199

200

201

202

203

204

205

generating disturbance at a range of scales by affecting vegetation cover locally or

extensively (e.g., active farming can be limited to a small enclosure or extend over the entire dune field).

\section{APPROACH APPLICATION AND WORKFLOW}

Figure 1 includes a workflow diagram to apply the approach introduced in this paper. The procedure is currently semi-quantitative. The first step is to calculate $M$ (section 2.1) and compare it with the categories established by Lancaster (Table 1). This can be used to obtain a general estimation of the expected degree of vegetation cover due to climate $(\mathrm{V}$; step 2) and whether temporal changes to this could be expected based on climatic trends. The third step consists of quantitative and/or qualitative estimations of actual dune mobility and/or observed vegetation cover $\left(\mathrm{V}_{\mathrm{o}}\right)$. This can be done using a variety of raw data including estimations of active sand (e.g., Muhs and Maat, 1993), measured rates of sand transport (Lancaster and Helm, 2000), or quantification of vegetation / bare sand (e.g., Jackson and Cooper, 2011; this article). The fourth step identifies potential causes for disturbance based on information contained in Table 3.

Estimations of $V_{0}$ in step 3 can be sensitive to area sizes, with localized disturbances in large dune fields being less pronounced because of the extent of the area under investigation. It is recommended that the percent of vegetation cover is estimated first for the entire dune field (e.g., $V_{\text {osefton }}$ in this paper) to gain an understanding of broad patterns in vegetation cover. This can then be followed by analyses at smaller spatial scales and at different locations $\left(\mathrm{V}_{\mathrm{o}}\right)$. These smaller areas for investigation should still be large enough for the analyses to remain at a landscape (not landform) scale and areal coverage can be simply 
206 selected to suit the objectives of the assessment. For example, in situations where dune

207 fields are sub-divided into different land uses, managers may want to assess the significance

208 of disturbance for individual sectors (e.g., section 6.1.2), or to examine trajectories in

209 mobility when stressors are removed, or management interventions are introduced.

210

211 The application of the procedure offers some flexibility. For example, it is possible to

212 complete step 1 and then proceed directly into calculating $V_{o i}$ at a smaller area in a

213 particular dune field to compare its evolution / state with respect to a predicted M. It is also

214 possible to start at step 4 and assess the likely effect of potential interventions in the

215 landscape identified in Table 3. The significance of particular disturbances can be estimated

216 using Table 2 to compare the magnitude of the disturbance (i.e., how much vegetation

217 cover changes because of the disturbance) vs. extent (i.e., the area affected by the

218 disturbance).

219

1. Calculate expected mobility (quantitative)

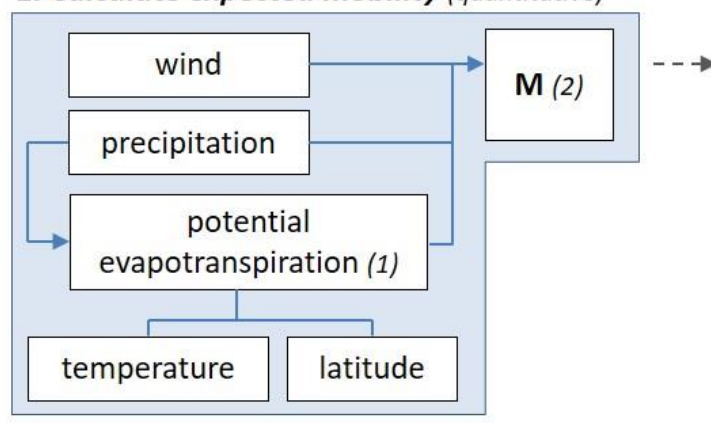

4. Analyse disturbance (D) (semi-quantitative)

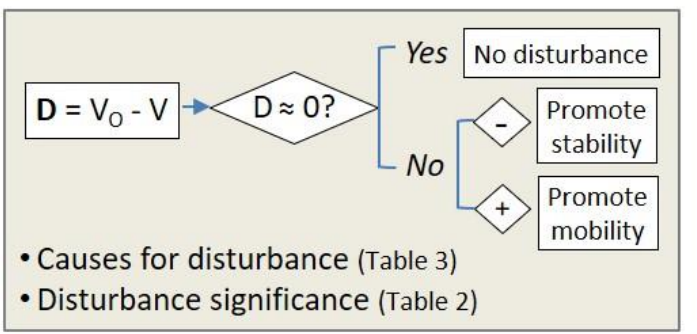

2. Estimate expected vegetation cover, $\boldsymbol{V}$ (qualitative)

Are there reasons to expect changes to vegetation cover based on climate?

\section{Observe mobility / vegetation cover}

\begin{tabular}{|c|c|}
\hline $\begin{array}{l}\% \text { vegetation or bare } \\
\text { sand }(3,5) \text { (quantitative) }\end{array}$ & $v_{0}$ \\
\hline or / and & \multirow{4}{*}{$\begin{array}{l}\text { Consider } \\
\text { the extent } \\
\text { or dune } \\
\text { area to be } \\
\text { explored } \\
\left(\mathrm{A}_{1}, \mathrm{~A}_{2}, \ldots\right. \\
\left.\mathrm{A}_{i}\right)\end{array}$} \\
\hline $\begin{array}{l}\text { rates of sand transport } \\
\text { (4) (quantitative) }\end{array}$ & \\
\hline or/and & \\
\hline $\begin{array}{l}\text { visual estimations of } \\
\text { dune crestal activity (5) } \\
\text { (qualitative) }\end{array}$ & \\
\hline
\end{tabular}


Figure 1. Workflow for the application of a routine to identify disturbance in dune systems. Step 1 only needs to be completed once for a dune field, with the evolution of $\mathrm{M}$ showing potential changes to mobility categories (Table 1) over time, and informing estimations of $V$ (step 2). Steps 3 and 4 can be repeated for different sections of a dune field. Inserted numbers in brackets make reference to the following publications: (1) Thornthwaite and Mather (1957), (2) Lancaster (1988), (3) several authors including this paper, Jackson and Cooper (2011), and Pye et al. (2014), (4) Lancaster and Helm (2000), (5) Muhs and Maat (1993).

221 The analysis of disturbances remains semi-quantitative as there is currently no methodology

222 (known to the authors) to calculate expected V. Step 4 was completed both as shown in 223 Figure 1 (i.e., semi-quantitatively) and using a numerical value for $\mathrm{V}$. The first allowed 224 testing the procedure 'as is', with disturbance examined using measured vegetation cover $225\left(V_{0}\right)$ against trends in mobility and qualitative estimations of $V$. The second allowed 226 illustrating how the approach could work if quantification of expected vegetation cover was possible. An average value of observed vegetation cover over the entire dune field was used 228 for this purpose (section 6.3.1).

\section{CASE STUDY SITE: THE SEFTON DUNES}

231 The approach was tested at the Sefton dunes (Merseyside, UK) (Figure 2), the largest coastal 232 dune field in England (Esteves et al., 2012). The dunes extend for over $16 \mathrm{~km}$ along the coast 233 and up to $4 \mathrm{~km}$ inland. They currently cover a total area of 2,150 ha although the dune complex has lost up to half its original extent to past development (Smith, 2009). The site is 235 divided into areas managed by different landowners including Sefton Council (ca. $610 \mathrm{Ha}$ ), 236 Natural England (ca. $370 \mathrm{Ha}$ ) and the National Trust (ca. $170 \mathrm{Ha}$ ), with other sections 237 occupied by golf courses, the Ministry of Defence (MoD), or the Lancashire Wildlife Trust. 
238 The Sefton dunes are subject to intense visitor pressure associated with the proximity to

239 large urban centres, with issues such as traffic jams and long queues for parking cited as a

240 primary management concern in planning documents (e.g., National Trust Public

241 Consultation Report, 2017). An estimated 1.2 million people visit the coast every year

242 (Sefton Coast Economic Plan, 2016) with the 3-km coastal walk around Formby ranked as

243 the $4^{\text {th }}$ most popular in Britain (Sefton's Natural Coast Tourism Marketing Plan, 2010).

244

245 The Sefton dunes were selected as a case study for two reasons: (1) the dunes benefit from

246 the existence of the information required in Figure 1, including aerial photography since

2471945 (to measure $V_{0}$ ), long-term climate data (to calculate $\mathrm{M}$ and estimate $\mathrm{V}$ ), and historical

248 records of anthropogenic activities (to explore D); (2) the division of the dune into areas

249 managed by different landowners provides an opportunity to test the performance of $D$ at

250 smaller spatial extents, and to investigate landscape complexities introduced by some of the

251 drivers included in Table 3.
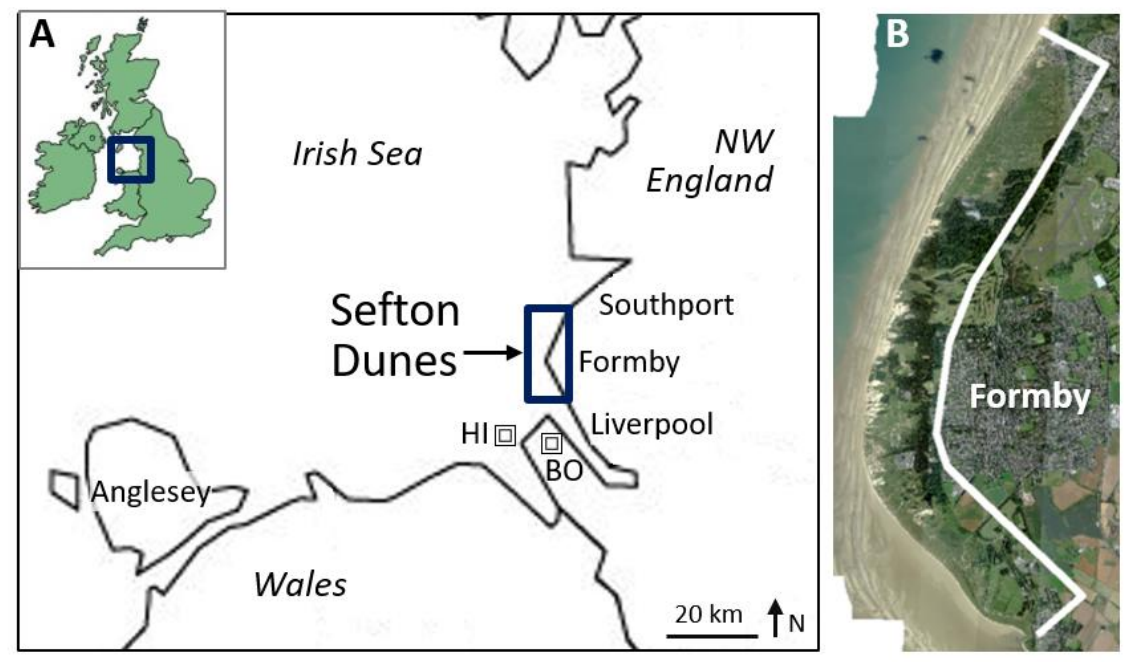

Figure 2. A) Location of the Sefton dunes, NW England (UK), main urban centres, and climate stations from the National Oceanography Centre (NOC): $\mathrm{HI}=$ Hilbre Island; $\mathrm{BO}=$ Bidston Observatory; $\mathrm{B}$ ) Landward and alongshore extent of study area. Background photographic mosaic from 2010 courtesy of Sefton Council. 


\section{METHODS}

\section{$254 \quad 5.1$ Climate and predicted dune mobility}

255 Climate analyses followed two steps. The first step focused on the calculation of $\mathrm{M}$ values

256 for the Sefton dunes (section 2.1) for the period 1930 to 2015. This required access to

257 conversion and computational tables developed by Thornthwaite and Mather (1957), mean

258 monthly records of temperature (Tmean) and precipitation (P), and wind speed (U).

259 Sediment sizes between the foredune and $100 \mathrm{~m}$ inland at Formby Point range between

$260 \quad 0.22-0.28 \mathrm{~mm}$ (Pye and Blott, 2010) and were used to calculate the frequency of winds

261 exceeding the minimum speed threshold (W) of $6.25 \mathrm{~m} \mathrm{~s}^{-1}$ (Bagnold, 1941). A 2-year period

262 of hourly wind data from a local station at Crosby ( $\mathrm{N}$ of Liverpool) was used to compare

263 wind records from the weather stations at Hilbre Island and Bidston (located further away

264 but including long-term data not available from Crosby; see below) with winds measured in

265 the vicinity of the Sefton dune field. The TM method has been widely applied to calculations

266 of water balances (e.g., Calvo, 1986; Stephenson, 1990; Black, 2007; Petalas, 2017) and it

267 allows obtaining values for potential evapotranspiration (PE) adjusted to latitude. Full

268 details and a step by step guide on how to apply the TM method can be found in

269 Thornthwait and Mather's (1957) original publication.

270

271 The second step consisted of statistical analyses of a range of meteorological variables to

272 investigate potential changes to the region's climate. A total of 8 variables were

273 investigated, including the three variables cited above (Tmean, $\mathrm{P}, \mathrm{U})$, humidity (HU), wind

274 gusts (Ug), atmospheric pressure (AP), and maximum (Tmax) and minimum (Tmin)

275 temperatures. Data were retrieved from two meteorological stations approximately $15 \mathrm{~km}$ 
276 SW of the Sefton dune field (Figure 2): the Bidston Observatory (BO; monthly values from 277 1930-2004) and Hilbre Island (HI; hourly values from 2005-2015), both available from the UK

278 National Oceanography Centre (NOC) Database. There were additional meteorological

279 stations in the region but only $\mathrm{BO}$ and $\mathrm{HI}$ were selected for the purpose of this article

280 because of their combined long-term records and completeness ( $\approx 100 \%$ in both cases). The 281 only exception was humidity, available from BO only from 1976.

282

283 Statistical analyses were based on the procedure by Gocic and Trajkovic (2013) and

284 included: (1) exploratory analysis using Mann-Kendall (MK) tests to identify the existence of 285 significant annual trends; and (2) quantification of trends using the Sen's slope estimator. Mann-Kendall (MK) tests (Mann 1945; Kendall 1975; Gilbert 1987) are a nonparametric form of monotonic trend regression analysis that have been applied widely in meteorology and hydrology (e.g., Douglas et al., 2000; Tabari et al., 2011). The MK test assumes that observations are independent and representative of true conditions at sampling times and permits analysis of upwards or downwards trends in climate data (e.g., Zhang et al., 2000; Su et al., 2006) even when time series have some missing observations (Helsel and Hirsch, 2002). Matlab codes developed by Burkey $(2006,2012)$ were applied to detect annual trends and to calculate Sen's slope. All tests were run at $5 \%$ and $1 \%$ significance levels.

\subsection{Measured vegetation cover and observed dune mobility}

296 Recent historical-scale (decadal) change in dune vegetation cover was examined using 16 297 aerial ortho-mosaics from 1945 to 2015 (Table 4). Previous studies applied unsupervised 298 classifications and pixel aggregation to quantify bare sand based on pixel brightness at a 299 variety of sites (e.g., Sellinger et al., 2000; Delgado-Fernandez and Davidson-Arnott, 2011; 
Pye et al., 2014). This technique was tested at Sefton but it led to considerable error. Most

301 mosaics included over 10 individual aerial photographs taken with varying environmental

302 conditions (e.g., changes in cloud cover or sun angle during the same flight) which led to

303 differences in illumination within the mosaic and incorrect pixel classification. The percent

304 of vegetation cover was therefore quantified by digitizing all areas of bare sand in each

305 mosaic in ArcGIS (Jackson and Cooper, 2011), which ensured greater accuracy. The process

306 was conducted by an expert analyst and independently reviewed by two different GIS users

307 for consistency.

308

309

Table 4. Ortho-mosaics analysed in this study (Courtesy of Sefton Council, CCrown Copyright). Pixel resolution

310 (PR) ranged from 0.25 to $1 \mathrm{~m}$ and the number of bands (NB) correspond to black and white images (1), RGB

311 photographs (3), and a Compact Airborne Spectrographic Imager (CASI) flight (28).

312

\begin{tabular}{|c|c|c|c|c|c|c|c|c|c|c|c|c|c|c|c|c|}
\hline $\begin{array}{l}\frac{1}{\pi} \\
\stackrel{\nu}{\nu}\end{array}$ & $\stackrel{\text { ڤn }}{\stackrel{-}{\sim}}$ & ન્નુ & 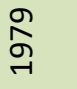 & 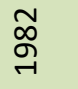 & $\begin{array}{l}\text { ১ } \\
\text { م্ન- }\end{array}$ & $\begin{array}{l}\text { م } \\
\text { م } \\
\text { - }\end{array}$ & જે & $\begin{array}{l}\text { ஜू } \\
\text { ু్ }\end{array}$ & ને & ने & ঃ & ণ্ণ & ஜํํ & 옹 & 공 & 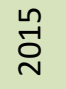 \\
\hline PR & 0.25 & 0.25 & 0.25 & 0.12 & 0.25 & 0.25 & 0.25 & 0.43 & 0.25 & 0.25 & 0.25 & 0.25 & 0.12 & 0.25 & 1 & 1 \\
\hline NB & 1 & 1 & 1 & 1 & 1 & 3 & 3 & 3 & 3 & 3 & 3 & 3 & 3 & 3 & 3 & 28 \\
\hline
\end{tabular}

315 Following general guidelines in section 3, observed vegetation $V_{0}$ was first calculated for the entire Sefton dune field system ( $\left.V_{\text {osefton }}\right)$. To gain insights into temporal changes to

317 vegetation cover at smaller spatial extents, the evolution of bare sand was analysed for different ownership zones (section 6.1.2). The effect of decreasing the extent of the area of

319 observation on measured vegetation cover was further explored using the 2015 dataset.

320 The Buffer tool in ArcGIS was used to create buffer areas of $500 \mathrm{~m}, 250 \mathrm{~m}$, and $125 \mathrm{~m}$ from 
321 the beach-dune boundary (i.e., the seaward limit of the dune field) inside ownership zones.

322 This allowed exploring disturbances at smaller spatial scales, and their relationship with

323 some of the variables identified in Table 3.

324

\section{$325 \quad 5.3$ Recreation and other anthropogenic activities}

326 The 2010 mosaic was acquired on a sunny weekend (Saturday $22^{\text {nd }}$ May) with large visitor

327 numbers, hence providing an opportunity to investigate the spatial distribution of people, 328 and the potential relationship between this driver and bare sand. The use of only one image

329 prevents temporal analysis, nonetheless snapshots or temporally limited visitor surveys can 330 provide important information about landscape trends and visitor behaviour (e.g., Tzatzanis 331 et al., 2003; Roca and Villares, 2008). Three datasets were digitized into point shapefiles: 1) 332 cars parked and the number of empty spaces, which allowed estimating saturation levels in 333 coastal car parks; 2) caravan sites; and 3) visitors, which were grouped into 'beach' or 'dune' 334 visitors. The $0.25 \mathrm{~m}$ pixel resolution of the mosaic made it possible to identify individual 335 visitors when these were separated from each other but not when they were clustered 336 (Figure 3). Hence, results presented in section 6.3.2 likely underestimate visitor numbers 337 because point features used to identify them represent both individuals and groups of 338 people. The Point Density tool from ArcGIS Spatial Analyst was used to obtain visitor density maps by calculating point feature densities for each cell of an output raster file (ESRI, 2016).

340 Two-dimensional cross-shore transects were extracted from these output density maps to 341 highlight differences in visitor concentrations around beach access points. 


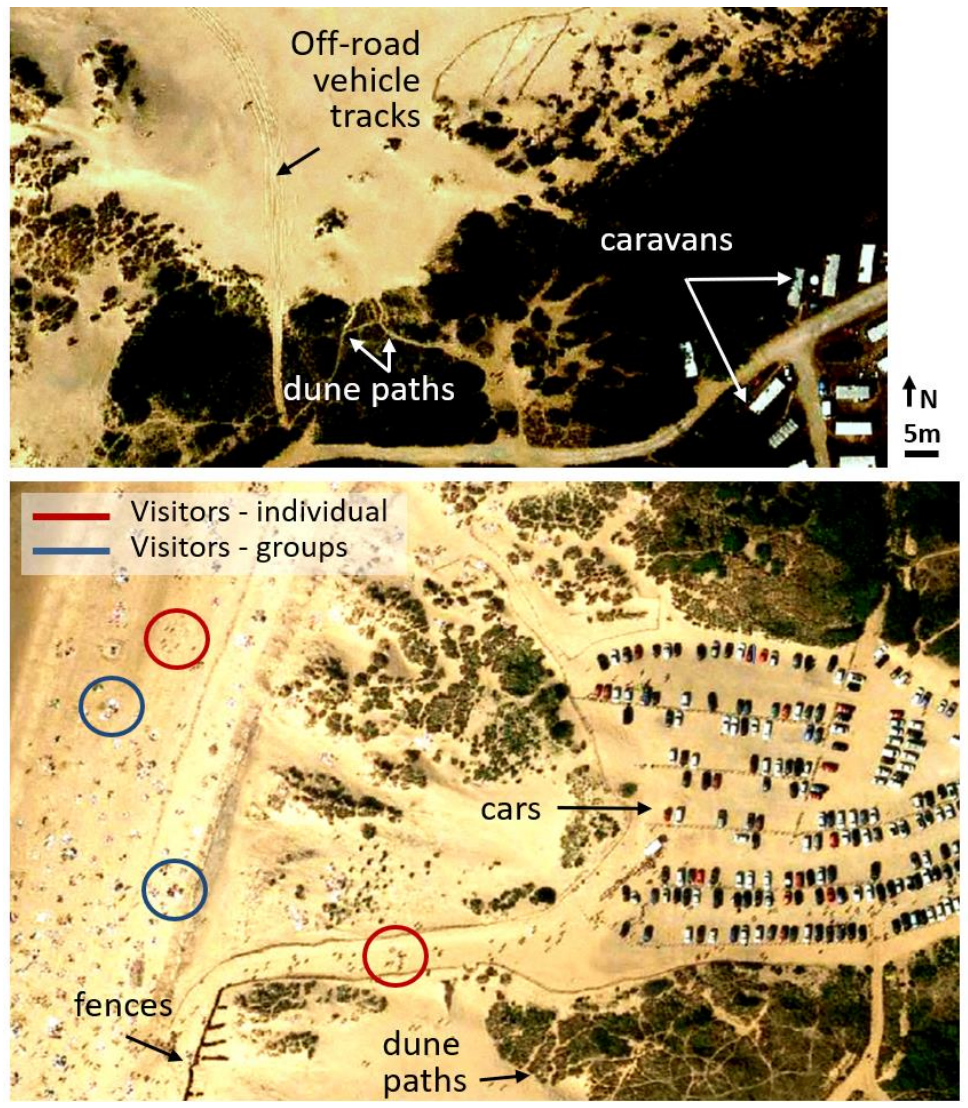

Figure 3. Example of features visible in the 2010 mosaic (images have been enhanced to improve visibility).

344 The Sefton dunes have experienced human interventions leading to artificial dune

345 stabilization (Smith, 2015). However, elaborating a comprehensive map of all of these was

346 challenging due to several limitations not least that management interventions aiming to

347 stabilise the dunes were not always visible in the aerial mosaics, or that fencing and planting

348 were also conducted in previously vegetated areas (and hence did not lead to a loss of bare

349 sand but to a loss of other surface types). Despite limitations, a quantitative estimation of

350 the effects of dune fencing on the rates of dune stabilization was attempted by focusing on

351 an area managed by Sefton Council where this process was clearly visible from 1979 to 1999

352 (section 6.3.3). Finally, the role played by other natural disturbances including coastal

353 erosion / accretion and types of colonizing plants was assessed qualitatively. 


\section{RESULTS}

\section{$356 \quad 6.1$ Observed changes in vegetation cover vs. bare sand}

\section{$357 \quad$ 6.1.1 Entire Sefton dune field}

358 Figure 4 includes three examples of the evolution of bare sand with dates separated roughly

359 every 3 decades. Most bare sand areas identified in 1945 had almost completely

360 disappeared by 2015. Visual inspection of the images suggests two processes leading to a

361 generalised loss of bare sand: 1) dune stabilization, especially to the $\mathrm{N}$ of Formby Point and

362 in landward areas of the dune field; and 2) costal erosion, with the recession of Formby

363 Point being responsible for the loss of many mobile dunes at this location from 1945 to

3642015 . Coastal accretion to the $\mathrm{N}$ and $\mathrm{S}$ of Formby Point resulted in mostly vegetated coastal

365 dunes, with bare sand concentrating predominantly at the foredune stoss slope in these two

366 areas and rapidly decreasing landwards from the frontal dunes. Bare sand patches around

367 Formby Point in 2015 were larger and extended inland to a greater degree.
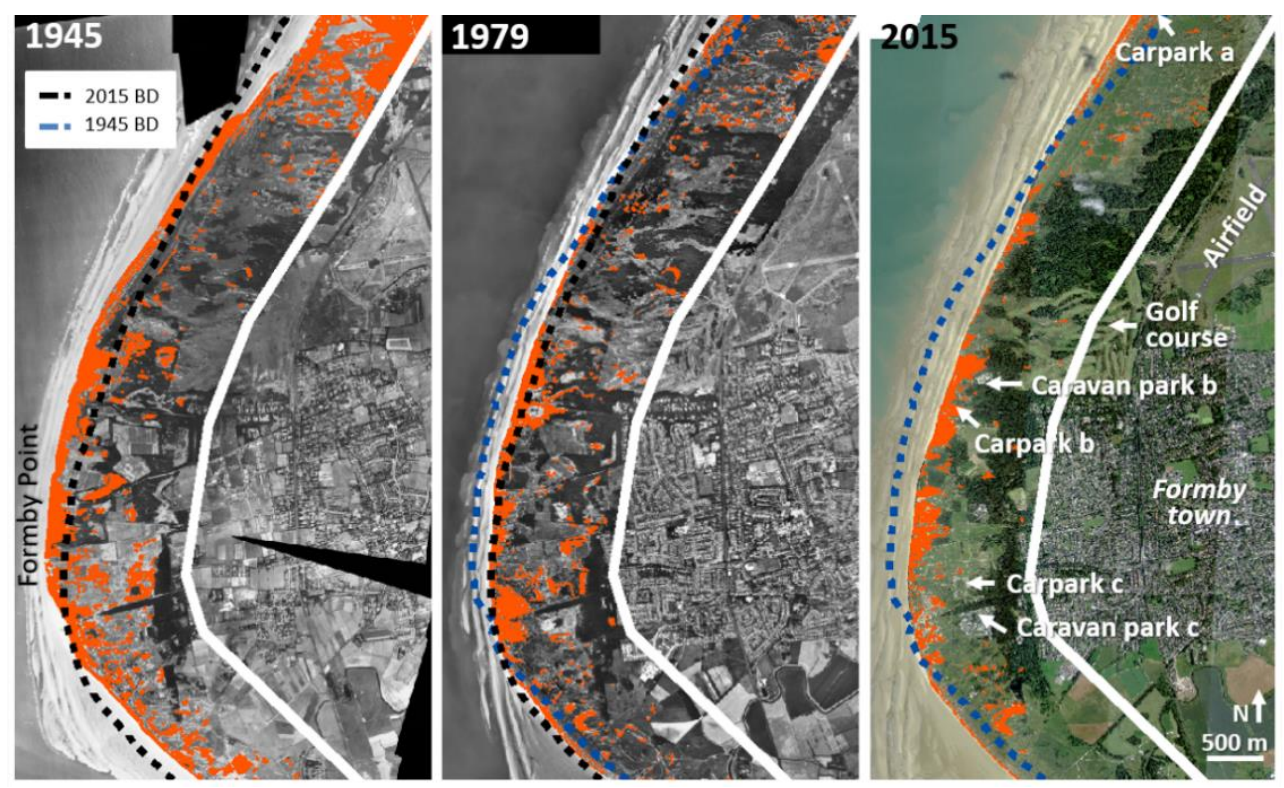

Figure 4. Examples of maps of bare sand every ca. 3 decades showing the location of bare sand patches. The 1945 beach-dune boundary (BD) is included in 1979 and 2015 maps, and the 2015 BD is included in 1945 
and 1979 to show shoreline changes. Large amounts of mobile dunes were lost due to coastal erosion at Formby point from 1945 to 1979 . Coastal accretion to the $\mathrm{N}$ and S was in the form of mostly stable coastal dunes.

370 Detailed temporal analyses of the percent of vegetation cover vs. bare sand indicates that

$371 \quad V_{\text {osefton }}$ values were always above $80 \%$ when considering the full extent of the dune field and 372 ranged from a minimum of $83 \%$ (1945) to a maximum of $98 \%$ (1989) (Figure 5).

373

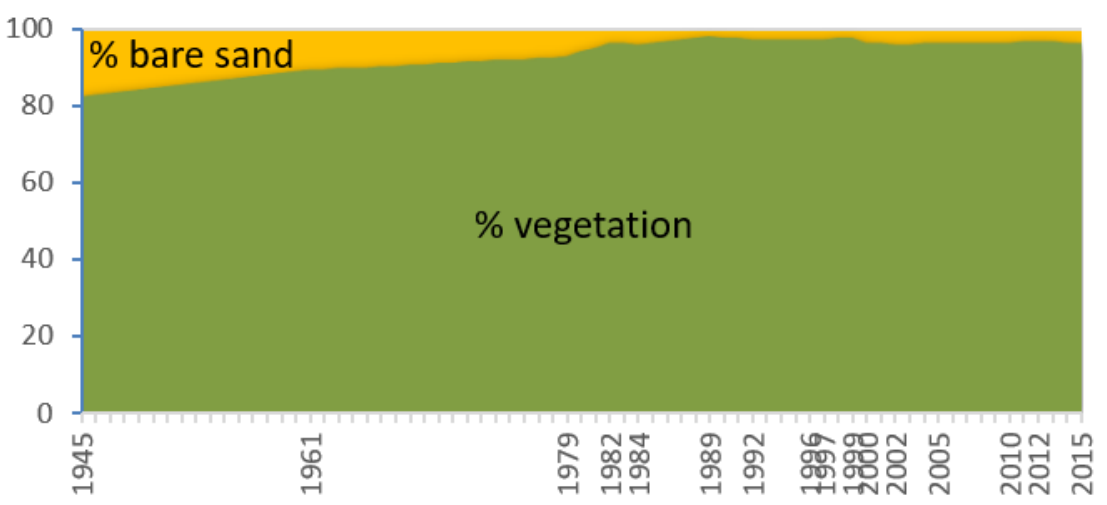

Figure 5. Percent change in area of vegetation cover vs. bare sand at the Sefton dunes (1945-2015).

374

\section{$375 \quad$ 6.1.2 Ownership sectors and buffer zones}

376 Figure 6 focuses on the overall decrease of bare sand from the Sefton dunes, subdivided

377 into ownership sectors. In general, the dune field lost 120 ha of bare sand from 1945 to

3781989 at a rate of 2.7 ha $\mathrm{yr}^{-1}$ but gained 20 ha of bare sand from 1989 to 2015 at a rate of 0.8

379 ha $\mathrm{yr}^{-1}$. In 1945, most bare sand concentrated in areas managed by Natural England (37\%)

380 and Sefton Council (38\%), with the National Trust and MoD each accounting for $8.5 \%$ of the

381 total amount. By 1982, only negligible quantities of bare sand remained in golf courses,

$382 \mathrm{MoD}$, and other small dune areas. The gain in bare sand during the second part of the study 
384 half (59\%) of the total bare sand in the entire dune system by 2015

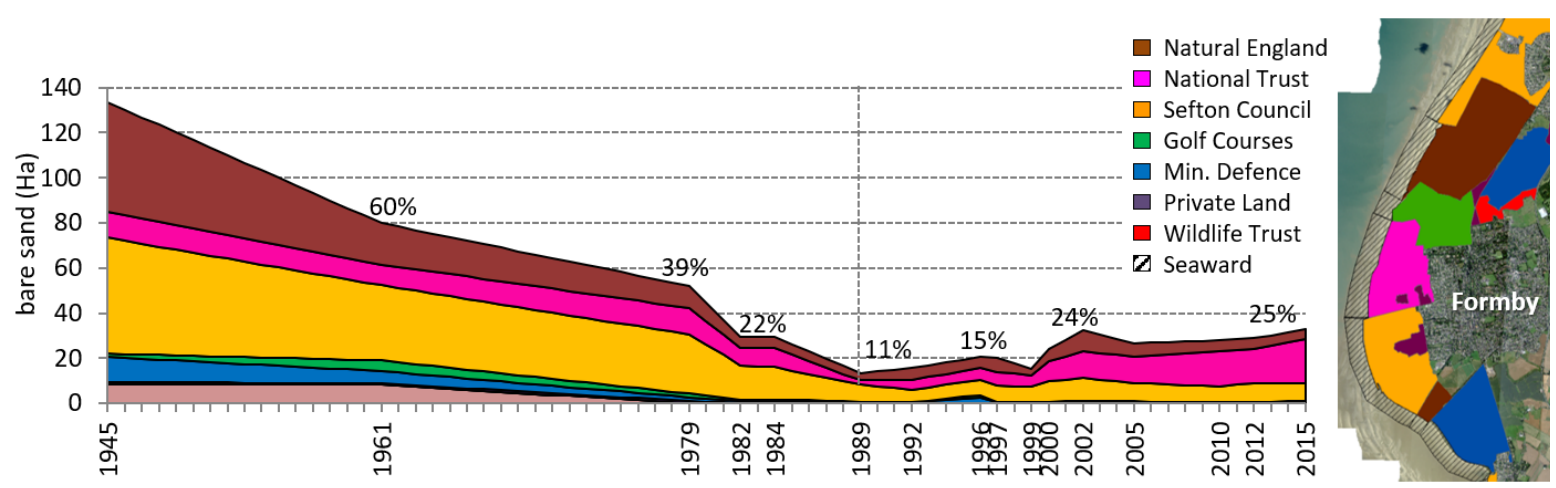

Figure 6. Temporal patterns in dune stabilization for the Sefton dune field subdivided by ownership areas (inset). The contribution to the total reduction of bare sand cover (ha) is expressed by the width of areas within the graph. Numbers at various points above the graph indicate \%bare sand cover at differing times compared to that present in 1945.

Spatial analyses using buffer zones on the 2015 aerial mosaic (Figures 7A, B) suggest that some of the general patterns described above were more distinct when adjusting the size of the area under investigation. Despite larger concentrations of bare sand in the National Trust sector, percentages in vegetation cover over this and other zones were similar and ranged from 89 to $99 \%$ when the $1 \mathrm{~km}$ buffer zone was used (i.e., the original study site landward extent shown in Figure 2B). The decrease in area extent with progressively smaller buffer zones accentuated the differences between the percent of vegetation cover in different ownership sectors. In general, vegetation cover decreased with buffer size in all sites, suggesting that bare sand tended to concentrate closer to shore. However, vegetation cover in most ownership sectors remained relatively high and above 85\% when using a 125 
398 its $125 \mathrm{~m}$ buffer zone.

399
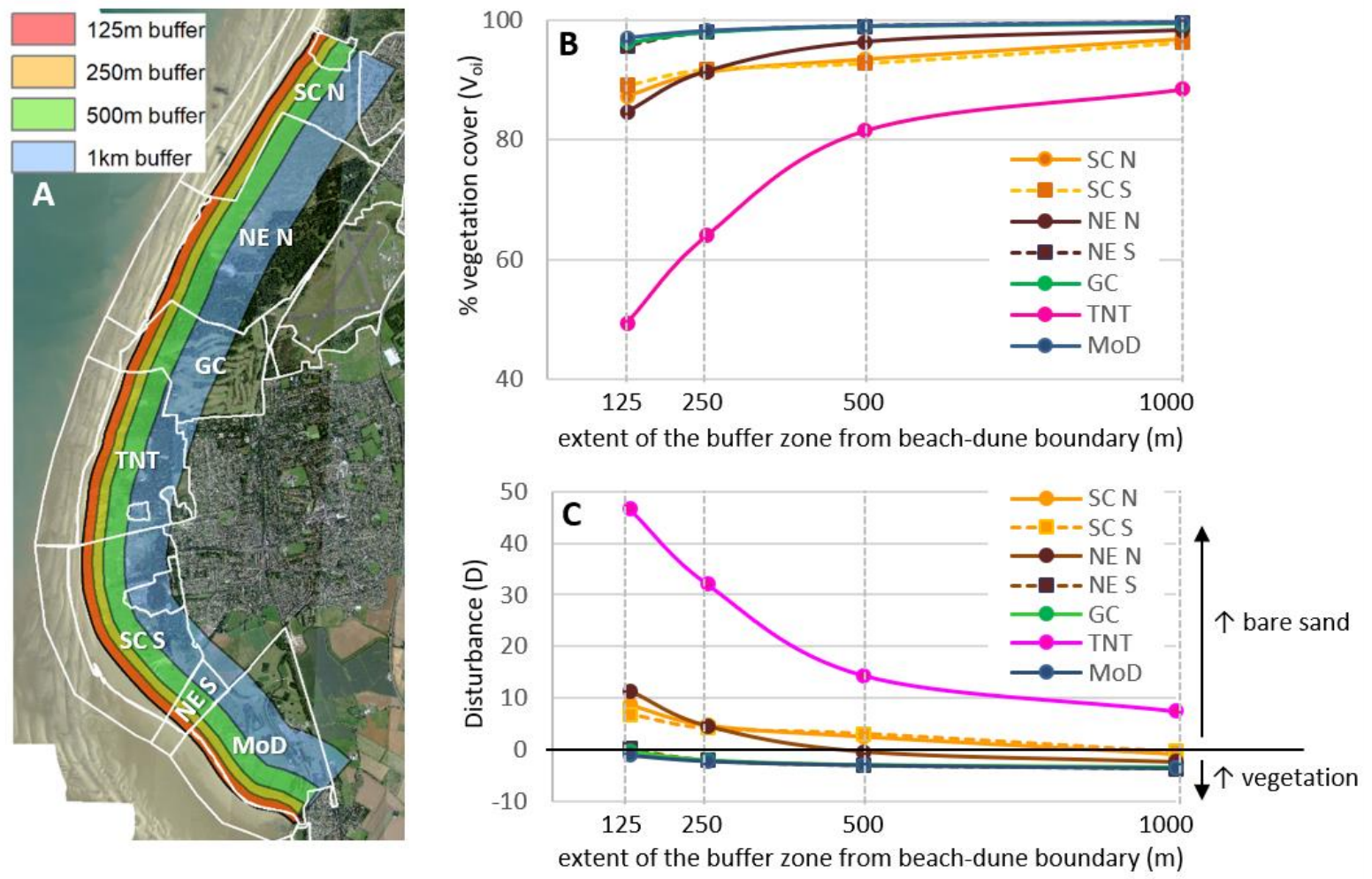

Figure 7. A) Buffer zones (calculated from the beach-dune area) over the 2015 aerial mosaic; B) Spatial changes in $\mathrm{V}_{\mathrm{o}}$ with different buffer zones and $\mathrm{C}$ ) associated disturbance levels.

400

6.2 Predicted dune mobility and climate

402 Statistical analyses showed significant changes in all climate variables at $1 \%$ significant levels

403 (Table 5; Figure 8), with the exception of precipitation, which did not show any significant

404 trends. Wind speeds and maximum wind gusts decreased at rates of $-0.01 \mathrm{~ms}^{-1}$ and -0.03

$405 \mathrm{~ms}^{-1} \mathrm{yr}^{-1}$, respectively, or the equivalent to a decrease of $-0.77 \mathrm{~ms}^{-1}$ and $-2.1 \mathrm{~ms}^{-1}$ over 70

406 years. Mean temperatures increased by $0.01^{\circ} \mathrm{C} \mathrm{yr}^{-1}$ and maximum and minimum

407 temperatures increased by $0.02{ }^{\circ} \mathrm{C} \mathrm{yr}^{-1}$, adding to $+0.7^{\circ} \mathrm{C}$ and $+1.12{ }^{\circ} \mathrm{C}$ over 70 years,

408 respectively. Humidity showed an increasing trend from 1979 to 2015 of $+0.19 \% \mathrm{yr}^{-1}$. 
411 Table 5. Results of statistical tests for changes in climate variables included in Figure 8.

412

\begin{tabular}{ll}
\hline Variable (year average) & Sen's slope \\
\hline Wind Speed (U) & -0.011 \\
\hline Max Wind Gust (Ug) & -0.030 \\
\hline Minimum Temperature (Tmin) & 0.016 \\
\hline Maximum Temperature (Tmax) & 0.016 \\
\hline Mean Temperature (Tmean) & 0.010
\end{tabular}
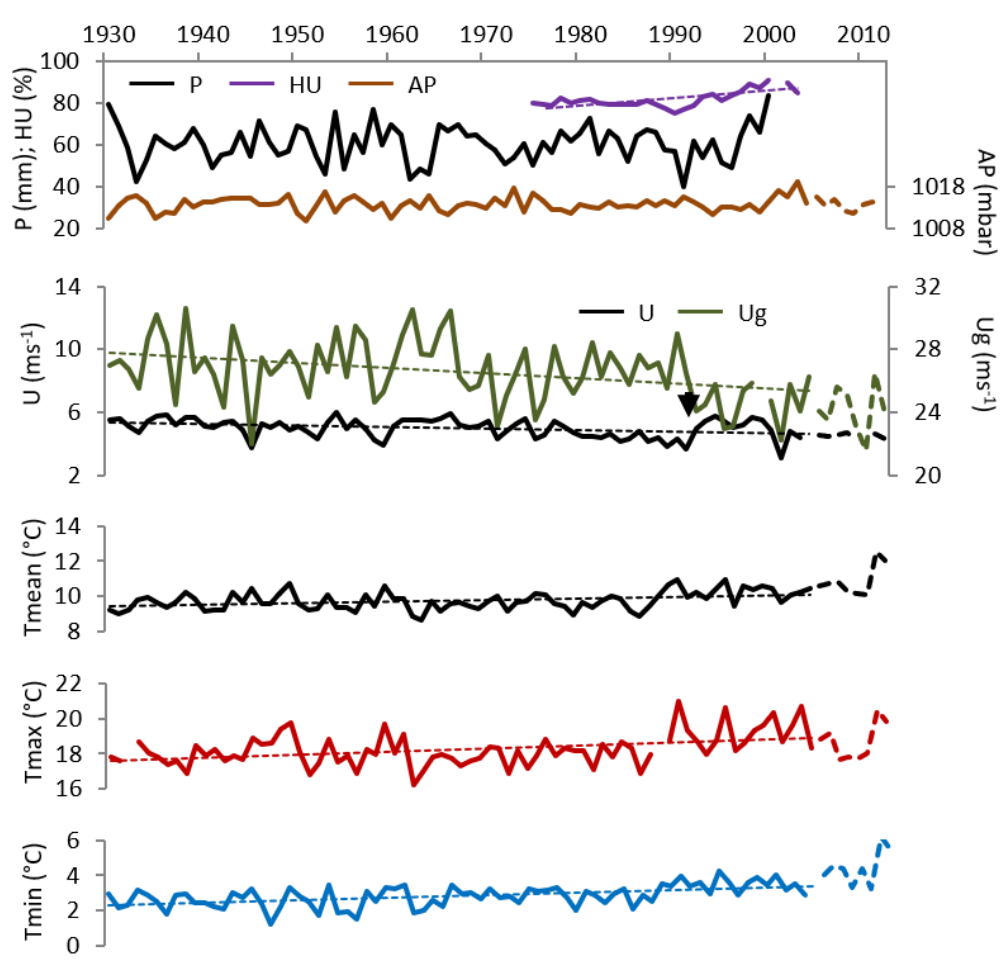

Figure 8. Annual records of precipitation (P), humidity (HU) and atmospheric pressure (AP) (top); wind speed (U) and maximum wind gust (Ug) (middle); and mean (Tmean), maximum (Tmax) and minimum (Tmin) temperatures (bottom) using data from from BO (solid line) and $\mathrm{HI}$ (dash line). Trend lines added only for time series showing statistically significant changes (Sen slopes in table 4). 
416 The average predicted mobility index for the Sefton dunes was $M=24$, indicating fully

417 inactive dunes (Table 1). Figure 9A shows yearly and 5-yr moving averages, with $\mathrm{M}$ values

418 always below the threshold of 50 , suggesting that climatic conditions from the 1930s have

419 consistently favoured a fully stable dune field, and that changes to $M$ were not expected 420 given rainfall and PE values.

421

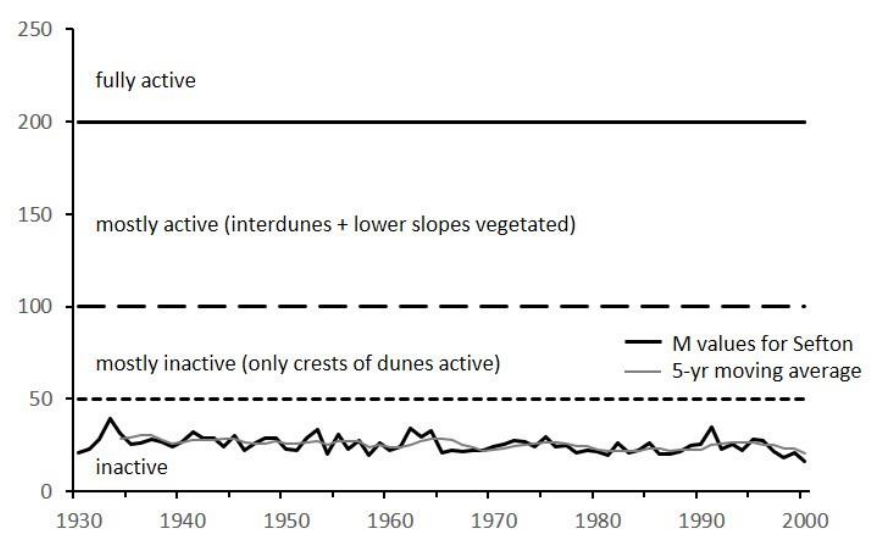

Figure 9. Temporal analysis of dune mobility (M) for the case of the Sefton dunes based on Lancaster's (1988) M categories.

\subsection{Disturbance and driver analyses}

\section{$424 \quad 6.3 .1$ Disturbance significance}

425 The comparison of $M$ with changes to bare sand (e.g., Figure 6) allows identifying areas

426 where trends in observed vegetation cover do not follow those expected due to climate.

427 Examples of these disturbances include increases in bare sand in the National Trust zone

428 since the 1990s, or the gradual decrease of bare sand in most other zones within the dune

429 field from 1945 to 1989. Additional to qualitative analyses, disturbance could also be

430 quantified if calculations of expected $\mathrm{V}$ due to climate were possible. Following the rationale 
431 in section 3 and with the objective of illustrating a fully numerical procedure, the average

432 value of measured vegetation cover for the entire Sefton dune field since $1989\left(V_{\text {oSefton }}=\right.$

$43396 \%$; Figure 5) was used as a general estimation of $\mathrm{V}$ (see discussion section 7.1). This value

434 is representative of relatively constant vegetation cover during the last 30 years of the study

435 period and allowed calculating disturbance levels (D; Eq. 1) for different ownership sectors

436 and buffer zones. Results are displayed in Figure $7 C . D_{i} \approx 0$ for all sectors when large areas of

437 the dune field were considered (1000 - $500 \mathrm{~m}$ buffers). $D_{i}$ increased to $\approx 5-10$ for areas

438 managed by Sefton Council and Natural England using $250 \mathrm{~m}$ and $120 \mathrm{~m}$ buffers. The

439 National Trust (TNT) zone showed disturbance levels that clearly exceeded the range of $D_{i}$

440 values observed elsewhere in the dune system with $D_{T N T}=32$ to 47 for buffer zones of 250

$441 \mathrm{~m}$ and $125 \mathrm{~m}$, respectively.

442

$443 \quad$ 6.3.2 Anthropogenic activities leading to increases in bare sand

444 Figure 10 shows visitor patterns observed from the 2010 aerial mosaic and co-located bare

445 sand areas. A total of 3,012 visitors (or groups of visitors) were identified, including 2550

446 'beach visitors' and 462 'dune visitors'. Up to $86 \%$ of all visitors concentrated around

447 carparks, with most (81\%) concentrating close to carparks $a$ and $b$. All carparks were over

$44870 \%$ full. Despite similar visitor numbers close to carparks $a$ (Sefton Council N) and $b$ (The

449 National Trust), disturbance levels in these two areas were different (Figure 7C), indicating

450 potential differences in recreation pressures. Carpark $a$ was at the beach and extended for

451 over 1,700 $\mathrm{m}$ alongshore hence providing easy access to more distant areas. 

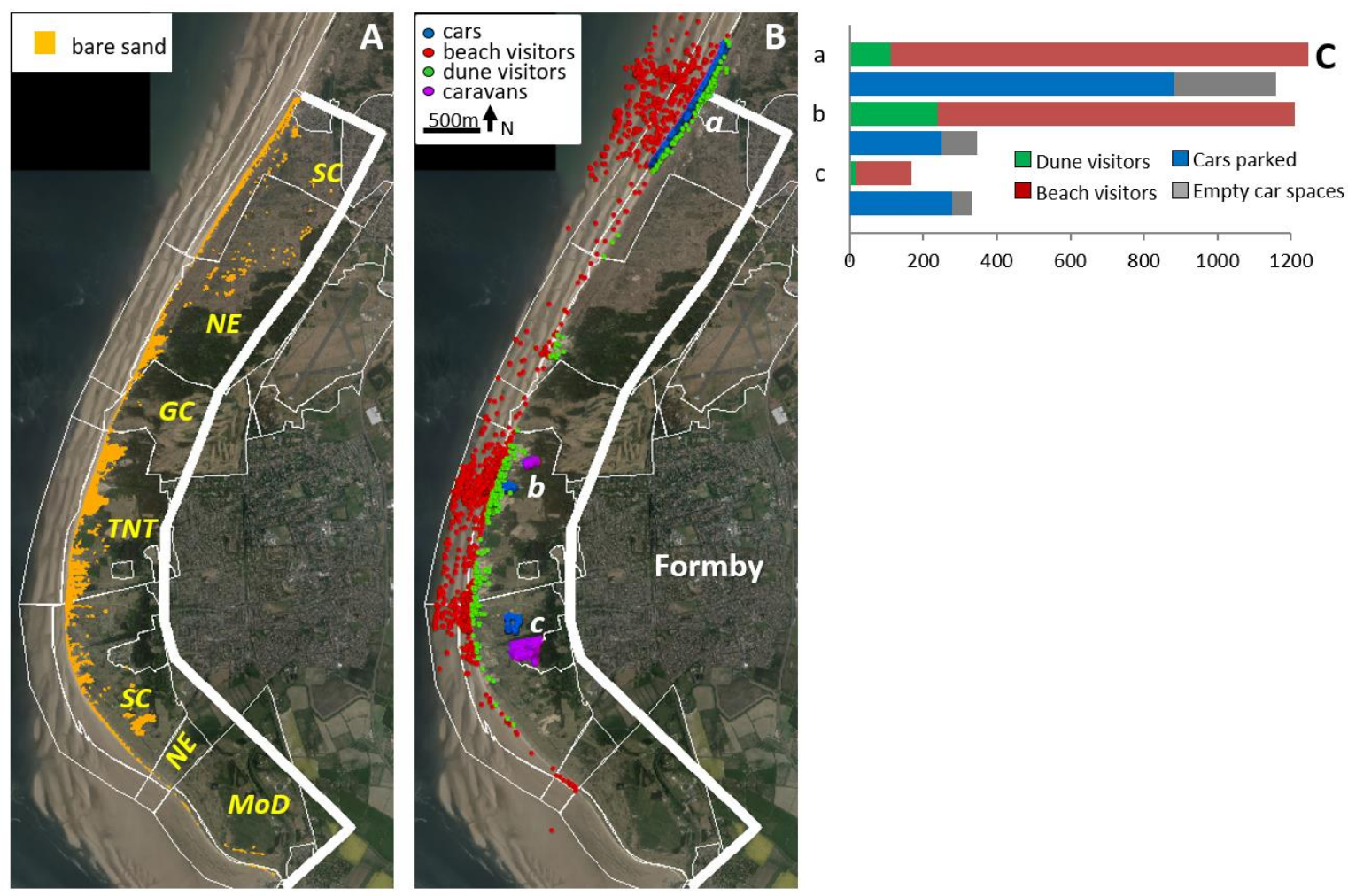

Figure 10. Spatial patterns of bare sand (A), visitor distribution (B), and visitor numbers $(C)$ along the Sefton coast on the 22 May 2010. Extent of the study site and limits of ownership sectors have been included. SC: Sefton Council; NT: Natural England; GC: Golf Courses; TNT: The National Trust; MoD: Ministry of Defence.

454 This was associated with lower visitor densities around its entry point (Figure 11A). Carpark

$455 \quad b$ was located inside the dune system and was associated to larger visitor densities over the

456 dunes and at its beach entry point (Figure 11B). Carpark $c$ was also located inside the dune

457 field and visitor patterns here were similar to those at carpark $b$. Visitor densities were

458 however lower than in $b$ because of smaller visitor numbers (compare Figures 10C and 11B).

459 Visitor densities around $b$ were 2.5 times larger than around the other two sites (Figure 11C)

460 but peak densities were roughly at the same distance cross-shore at the three locations (ca.

46150 m seawards from the beach-dune boundary). 

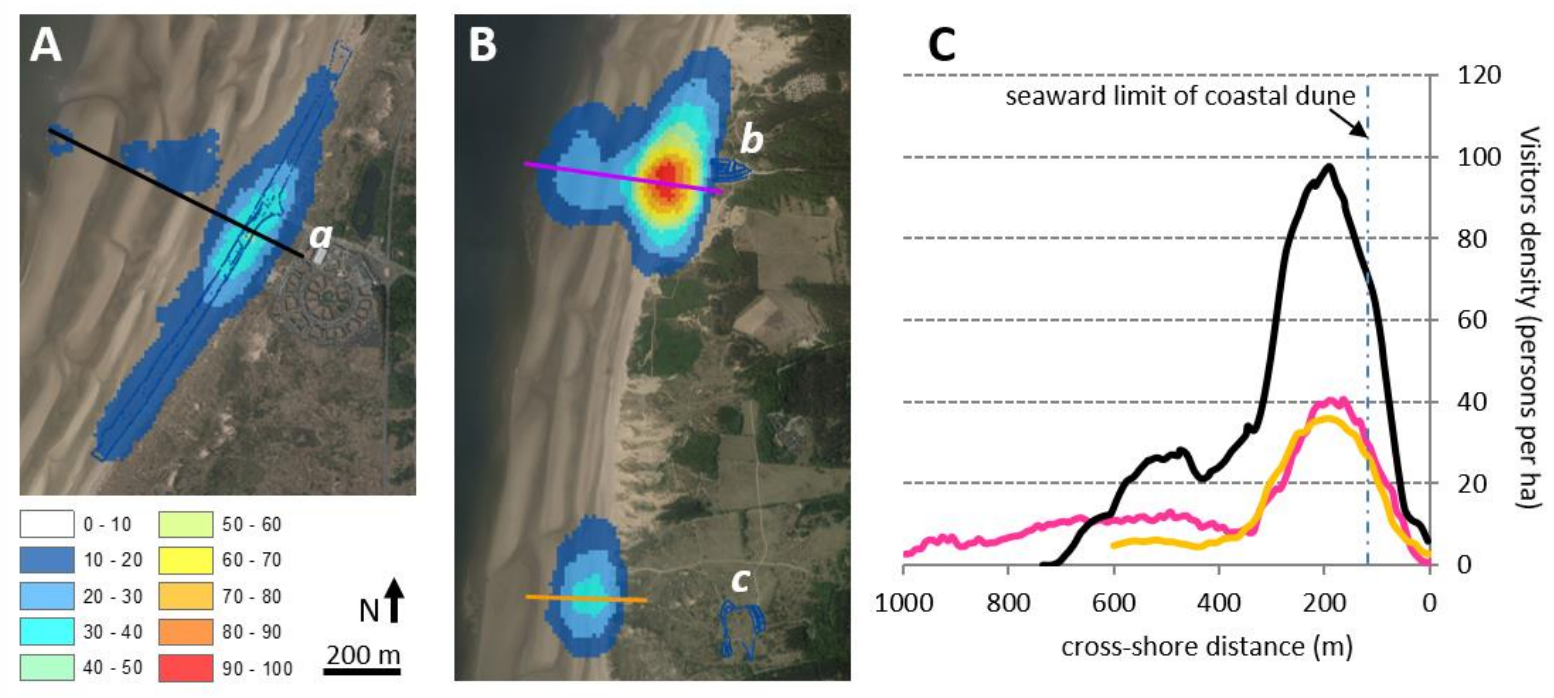

Figure 11. A-B) Visitor density maps (locations in Figure 10). C) Cross-shore variation in visitors' density along transects, from 150 m landwards from the beach-dune boundary to the end of the density map at the beach.

\subsubsection{Anthropogenic activities leading to dune stabilization and other natural disturbances}

465 The aerial mosaic in 1979 showed the presence of fences across a bare sand area located close to carpark c (Figure 12). Fencing was followed by rapid vegetation colonization by

4671989 and the stabilization of up to $91 \%$ of bare sand by 1999 , at a rate of $4.6 \% \mathrm{yr}^{-1}$. This was double stabilization rate observed when considering the entire Sefton dune field, which lost

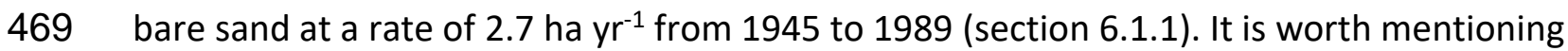

470 that stabilization in this area was also caused by the removal of stressors which led to dune

471 instability in the past. This included a relatively steady coastline at this location (Figure 4)

472 and a reduction of visitor pressure, with a clear path leading from carpark $c$ to location 1 at

473 the beach being established in 1984 and resulting in less people spreading over the dunes. 

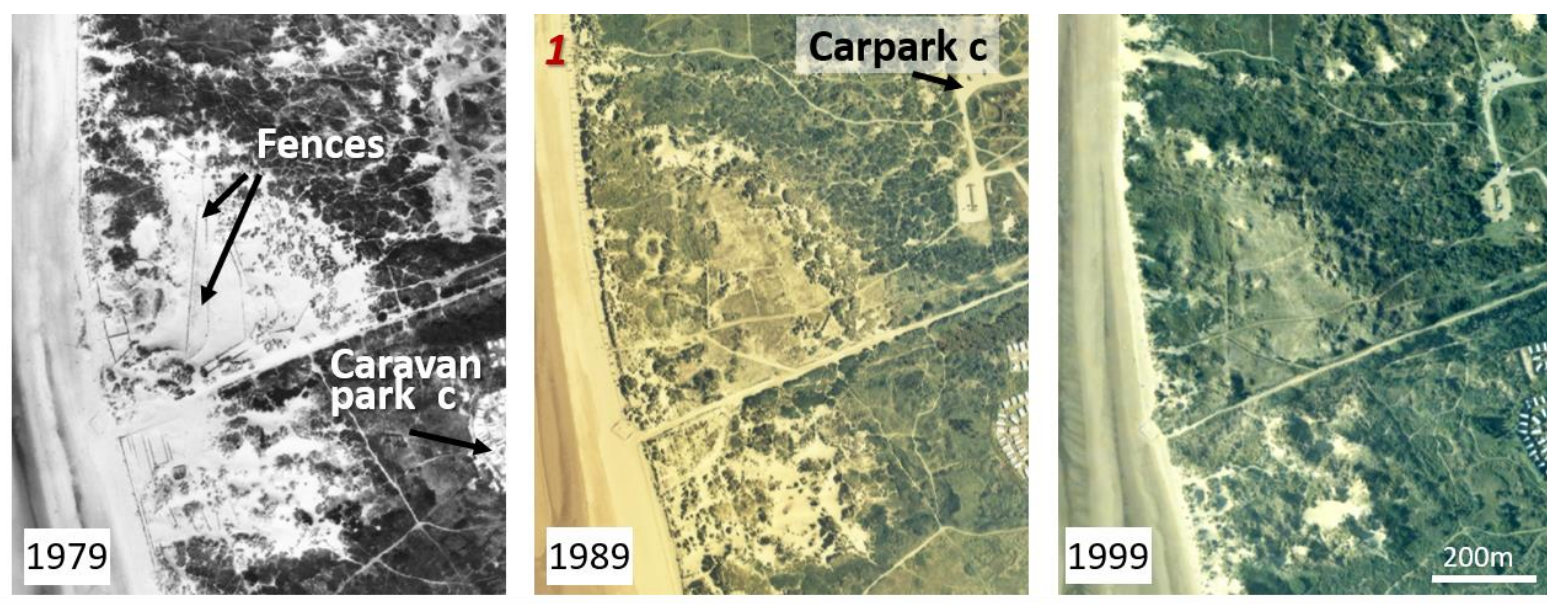

Figure 12. Effect of fencing close to carpark c (location sin Figures 3 and 10), showing rapid dune stabilization in $10-20$ years after the intervention. Dune stabilization in this area also reflects the partial removal of past stressors including less visitor pressure in 1999 compared to 1979 , and a relatively stable coastline providing greater carrying capacity to drivers of positive disturbance compared to areas close to carpark b (Figure 10).

476 The predominant colonizing plant at the site is Amophila arenaria or marram grass, a native

477 species that thrives under sand burial (Table 3). Accreting areas with plenty of sediment

478 supply are hence likely to stabilize rapidly. At the Sefton coast, zones subject to coastal

479 progradation were also subject to dune stabilization, with several examples of newly formed

480 foredunes being rapidly colonized by grass. Areas subject to coastal retreat (e.g., the

481 National Trust) were less vegetated, with marine erosion likely magnifying the contribution

482 of visitor pressure.

\section{DISCUSSION}

\subsection{Advantages and limitations of $M, V$, and $D$}

486 An improved methodology to predict coastal dune field activity is beyond the scope of this 
models (e.g., Hugenholtz and Wolfe, 2005; Yizhaq et al., 2009). We highlight here that the purpose of this work was not to test the application of existing mobility indices to the case

490 of coastal dunes, but to provide a framework that allows separation of what is natural from 491 what is not, and informs coastal dune managers of the 'expected' dune mobility state based 492 on climate. The objective of our use of an M-type approach is to establish a threshold, based on potential evapotranspiration, with vegetation cover decreasing as the magnitude of the

494 difference between PE and actual evapotranspiration increases.

496 Quantitative analyses of disturbance significance in the future could be explored by

497 developing methods to calculate V. Tests conducted on the Sefton dunes demonstrate that

498 the current semi-quantitative $D$ index is effective at identifying disturbances and excessive

499 deviations of the system from its expected mean state. The index performed well in the case

500 of disturbances leading to increases in bare sand (+D) and could be applied to predict the

501 likely trajectory of coastal dune systems following interventions leading to the removal of

502 native or invasive plant species (e.g., Konlecher, 2018; Ruessink et al., 2018) or following

503 large-scale storm impacts destroying dune vegetation (e.g., Carter et al., 2018).

504 Disturbances leading to stabilization (-D) were negligible at the spatial extents explored here

505 (Figure 7C) but observations on an area subject to fencing suggested that this management

506 intervention was effective at speeding up dune stabilization (Figure 12), in line with

507 experiences elsewhere (e.g., Dahm et al., 2005). It is argued here that a clear -D signal was

508 not detected in the case of Sefton because the dunes were in general already stable. The

509 range of positive and negative $D$ values depends on $\mathrm{V}$. At locations with low predicted $\mathrm{M}$

510 and hence high estimated $\mathrm{V}$, it is unlikely to have excessive disturbances leading to artificial

511 stabilization. The $D$ index should be tested in arid or semi-arid coastal dune fields, where its 
512 application to detect disturbances leading to increases in bare sand will be limited but its

513 ability to detect disturbances leading to dune stabilization not explained by climate could be

514 high. In arid to semi-arid coastlines, rainfall (a key variable in M) plays a primary role in

515 determining the existence of nebkha vs foredune ridges, with variables such as vegetation

516 species and sediment supply controlling foredune type and nebkha density (Hesp et al.,

517 2018). Recent analyses by García-Romero et al. (2018) suggests the potential for the $D$ index

518 to perform well in arid dune fields, with localized increases in vegetation cover linked to

519 direct human impacts and the growth of urbanization at their study site instead of changes

520 to climate $(\mathrm{M})$.

521

\subsection{Disturbance location}

523 The damage that pedestrians, cyclists, and motorbikes cause to coastal dune vegetation has

524 long been recognized (e.g., Boorman and Fuller, 1977; McDonnell, 1981; Andersen, 1995;

525 Fenu et al., 2013; Hesp et al., 2010). This damage can be enhanced by its location within the 526 dune field. The seaward-most sections of coastal dunes (embryo dunes and foredunes) are

527 subject to both marine and wind action. In these locations, highly specialized pioneer

528 grasses play a key role in dune building by binding the sand together. Uncontrolled

529 recreation destroys dune vegetation (McDonnell, 1981; Tzatzanis et al., 2003; Dahm et al.,

530 2005; Jackson and Nordstrom, 2011; El Mrini et al., 2012), and can completely prevent or

531 slow down plant colonization at the beach-dune boundary where the vegetation is most

532 sensitive to disturbance and only just establishing itself. This weakens coastal dunes making

533 them more vulnerable to both wave and aeolian erosion. In the case of Sefton, significant

534 disturbance $(D+)$ observed at the National Trust zone (Figure $7 C$ ) were associated with bare 
sand areas at the frontal dunes, with visitor pressure magnifying the contribution of marine erosion.

537

538 Additionally, certain locations may be more resilient to the stressors they are subject to. For

539 example, two locations may experience comparable levels of a cause for disturbance, but

540 the magnitude and longevity of the disturbance may be less or more due to its resilience. At

541 Sefton, longshore areas with positive sediment budgets (i.e., coastal accretion) appeared to

542 'cope' better with the same stressor (e.g., pedestrians over the dunes), or to recover from it

543 more rapidly, compared to areas prone to coastal erosion with lower resilience to

544 disturbances (Figure 4, areas around carpark $a$ and $b$, respectively).

545

\subsection{Historical complexities, dune cycles, and additional drivers}

547 In line with global trends in increasing temperature (Hughes, 2000; Xu et al., 2016) and

548 decreasing wind speeds (McVicar et al., 2012; Vautard et al., 2010), there was significant

549 warming and wind stilling in the Sefton region from 1930 to 2015. However, predicted M

550 values for the same study period did not significantly change and hence there are no

551 indications that the observed climate variability is related to changes in vegetation cover at

552 this location. This is in line with long-term trends in species composition of Scottish coastal

553 dunes (Pakeman et al., 2015) and suggests that climate change favouring vegetation growth

554 plays a secondary role when mobility is already limited.

555

556 Low M values for the Sefton dunes in the 1930s suggest a climate that favoured a fully

557 stable landscape at the beginning of the study period. It is worth noting that this agrees with 558 actual observations of vegetation cover for the entire dune field around the same time, with 
$559 V_{\text {osefton }} \approx 83 \%$ in 1945 (Figure 5). There was, however, more bare sand in 1945 compared to

560 the present day (i.e., 2015). The lack of evidence supporting that this reduction in bare sand 561 was linked to climatic change could be explained in several ways:

(1) Other variables not included in table 3 could have driven increases in vegetation

563 cover during the study period. There is strong evidence of changes to atmospheric composition including increases in $\mathrm{CO}_{2}$ and atmospheric nutrients at a planetary level

565 (Bennett et al., 2001; Galloway et al., 2008; Keenan et al., 2016) with more bio-available nitrogen and phosphorous leading to soil and plant fertilization (e.g., Keenan et al., 2016),

567 and hence potentially dune stabilization.

2) Disturbances leading to increases in bare sand in the past (instead of, or additional

569 to disturbances leading to stabilization in recent decades) could have been responsible for

570 larger amounts of bare sand in 1945. At Sefton, land uses promoting artificial vegetation

571 disturbance are well-documented, including large-scale sand-winning and rabbit-warrening

572 (e.g., Cowell, 2008; Smith, 2009, 2012; Roberts, 2014; Table 3). The latter was a major land-

573 use for several centuries, with rabbit populations markedly decreasing due to myxomatosis

574 from the late 1950s onwards. Sand extraction also disappeared during the 1950s and 1960s,

575 allowing the landscape to recover from this disturbance. The decline in rabbit populations

576 has recently been identified as a primary cause for dune stabilization in dune fields in

577 Australia (Moulton et al., 2018), and human activities have been cited as responsible for

578 vegetation degradation and dune mobility in large regions in China over timescales of 579 centuries (Guo et al., 2018). It is worth stressing that natural disturbances can also lead to 580 significant divergencies from expected coastal dune mobility states. For example, aerial 581 photography from the 1930s at Greenwich Dunes (Canada) shows transgressive dunes 582 extending hundreds of metres inland, and limited vegetation cover. Analyses conducted by 
584 result of a catastrophic storm overwash event in the 1920s and hence a natural disturbance.

585 As expected from the climate of the region, vegetation gradually re-colonized the site, decreasing the disturbance significance over time. The process of dune healing and post-

587 storm dune recovery varies for different locations (Houser et al., 2015) and can take up to several decades (Matthew et al., 2010).

3) Coastal dunes go through cycles of activity and inactivity in response to large-scale climate fluctuations (Monaghan et al., 2018), and evolve into various stages characterised

591 by different landscape complexity and vegetation richness (Hesp, 2013). Many coastal dunes 592 worldwide have gone through a period of declining dune activity and adaptation to 593 relatively warmer conditions since $\approx 1850$, following the termination of a pulse in aeolian 594 events during the Little Ice Age (LIA; Clemmensen and Murray, 2006; Dezileau et al., 2011;

595 Costas et al., 2016; Dillenburg et al., 2018). Historical records on weather and climate in 596 Sefton indicate multiple periods of past dune activity alternating with dune stability over the 597 last 1,500 years, and lag times in dune response to climatic changes (Lewis, 2010).

598

599 All arguments above can co-exist, giving rise to complex landscapes that evolve as a result of 600 many drivers. Since $V_{0}$ is a function of $V$ and $D(E q .1$ ), some of the trends in dune 601 stabilization identified in many locations around the world (section 1) could be explained by 602 the predominant role played by one variable, or by the combination of several drivers acting 603 together. At any given time, $\mathrm{V}_{\mathrm{o}}$ reflects the climate of a region, drivers listed in Table 3, 604 changes to atmospheric composition, historical disturbances, lag responses, and dune 605 cycles. 


\subsection{Implications for management}

608 It is important that the relative contribution of drivers for coastal dune field vegetation

609 change is understood prior to adopting intervention strategies aimed at influencing dune

610 field evolution. The failure to recognize that cycles of dune mobility and blowout

611 development can be part of the natural evolution of a dune system has led in the past to

612 artificial stabilization of naturally active dunes. In these systems, previous planting and

613 fencing efforts, as well as the introduction of invasive species, are disturbing the landscape,

614 and hence mitigation of those impacts would seem desirable. Similarly, it is important to

615 tease out the reasons for increases in vegetation cover before attempting to intervene in

616 the landscape. On naturally inactive dunes where stability is expected based on the general

617 climate (e.g., humid coasts of the Caribbean), efforts to de-stabilize coastal dunes are in fact

618 a disturbance. In these cases, the likely trajectory that the system will follow once the

619 disturbance is removed is that of trying to re-stabilize itself. This explains why management

620 approaches aiming to artificially creating bare sand in temperate dune field systems are

621 ineffective in the long-term, with vegetation growing back only a few years after the

622 intervention (e.g., Arens et al., 2013) because the system is simply restoring itself.

623

624 Finally, the role played by different vegetation communities has not been considered in this

625 study but should be included in future analyses and in attempts to calculate V. Coastal dune

626 plant communities vary with succession, exposure, and water levels (Miller et al., 2010;

627 Kamps et al., 2008; Curreli et al., 2013). Ecological niche modelling suggests that plant

628 communities behave differently with climate change (Mendoza-González et al., 2013) but

629 some studies suggest that anthropogenic disturbances (e.g., invasion or removal of woody 
species) and changes due to succession (Pakeman et al., 2015) are primary drivers for

631 community shifts.

632

\section{CONCLUSIONS}

634 Identifying a single variable driving changes to vegetation cover in coastal dune fields is challenging because variations to bare sand result from the interaction of multiple drivers

636 (i.e., climate, sediment budgets, management actions, atmospheric composition, etc.). It is

637 likely that drivers act together with different degrees of predominance depending on the

638 location and characteristics of the coastal dune field under investigation. However, it is

639 possible to assume that the climate of a region (including climate perturbations, oscillations,

640 and climate change) is a primary control on dune vegetation cover, and that deviations from

641 the predicted mobility/stability state are due to disturbances (natural and/or

642 anthropogenic). This facilitates exploration of natural vs. human causes for changes in

643 vegetation cover and allows predicting the likely trajectory of a dune system if disturbances

644 are removed.

645

646 The approach adopted in this study was tested at the Sefton dunes, the largest coastal dune

647 field in England. Artificial disturbances included increases in bare sand generated by visitor

648 pressure $(+D)$, and relatively minor increases in the rate of vegetation growth via fencing

649 and planting (-D). A comparison between estimated and observed vegetation cover during

650 the 1940s suggested that the dune system could have been disturbed prior to the study

651 period, with past artificial disturbances primarily consisting of sand mining and rabbit-

652 warrening, and natural disturbances consisting of lag effects from previous cooler and

653 windier conditions. 
655 Detailed analyses by ownership sectors permitted identification of system deviations from

656 expected (average) vegetation cover. Human disturbances such as vegetation trampling and 657 uncontrolled visitor pressure had different effects along the coast and were responsible for 658 increases in bare sand in the area managed by The National Trust. Management implications 659 here consist on steps towards removing dune stressors to allow the system to restore itself, 660 should the aim of management be to preserve natural dune evolution. Hence, it is

661 recommended that visitor pressure is controlled, and human trampling is minimized or 662 prevented. There are many examples of successful dune restoration experiences worldwide, 663 including the use of boardwalks, information stalls and virtual fencing. Preventing further 664 artificial disturbances is particularly important at the seaward limit of coastal dune fields, 665 where human activities can interfere with beach-dune interaction and increase coastal 666 vulnerability to storms and extreme events.

667

\section{ACKNOWLEDGEMENTS}

669 This work was supported by the REF-IF programme at Edge Hill University [grant number 670 RDDELG13]. Aerial mosaics were kindly provided by Paul Wisse (Sefton Council C Crown 671 Copyright; Licence number 1000181192 2010). The authors are grateful to Phil Smith 672 (Sefton Coast Landscape Partnership), Paul Ashton (Biology Department, EHU) and Paul 673 Aplin (Geography Department, EHU) for comments on earlier material, as well as references 674 to unpublished information. Aneurin O'Neil (Centre for Ecology \& Hydrology, Lancaster) and 675 Susan Jones (Geography Department, EHU) assisted on climate and GIS analyses. 
Ash, J.E., and Wasson, R.J., 1983. Vegetation and sand mobility in the Australian desert dunefield. Zeitschrift fur Geomorphologie, 45(Supp.), pp. 7-25.

Andersen, U.V., 1995. Resistance of Danish coastal vegetation types to human trampling. Biological conservation, 71(3), pp. 223-230.

Arens, S.M., Mulder, J.P., Slings, Q.L., Geelen, L.H. and Damsma, P., 2013. Dynamic dune management, integrating objectives of nature development and coastal safety: examples from the Netherlands. Geomorphology, 199, pp. 205-213.

Avis, A.M., 1989. A review of coastal dune stabilization in the Cape Province of South Africa, Landscape and Urban Planning 18, pp. 55-68.

Bennett, E.M., Carpenter, S.R. and Caraco, N.F., 2001. Human Impact on Erodable Phosphorus and Eutrophication: A Global perspective increasing accumulation of phosphorus in soil threatens rivers, lakes, and coastal oceans with eutrophication. BioScience, 51(3), pp. 227-234.

Black, P. E., 2007. Revisiting the Thornthwaite and Mather Water Balance ${ }^{1}$. JAWRA Journal of the American Water Resources Association, 43, pp. 1604-1605. doi:10.1111/j.1752-1688.2007.00132.x

694 Boorman, L.A. and Fuller, R.M., 1977. Studies on the impact of paths on the dune vegetation 695 at Winterton, Norfolk, England. Biological Conservation, 12(3), pp. 203-216.

Bullard, J.E., Thomas, D.S.G., Livingstone, I. and Wiggs, G.F.S., 1997. Dune field activity and interactions with climatic variability in the southwest Kalahari Desert. Earth Surface Processes and Landforms, 22, pp. 165-174.

699 Burkey, J., 2006. A non-parametric monotonic trend test computing Mann-Kendall Tau, Tau-b, and Sen's Slope written in Mathworks-MATLAB implemented using matrix 
rotations. King County, Department of Natural Resources and Parks, Science and Technical Services section. Seattle, Washington. USA. http://www.mathworks.com/matlabcentral/fileexchange/authors/23983

Burkey, J., 2012. Seasonal Kendall Trend Test for Data with and without Searial Dependance. King County, Department of Natural Resources and Parks, Science and Technical Services section. Seattle, Washington. USA. https://uk.mathworks.com/matlabcentral/fileexchange/22389-seasonal-kendall$\underline{\text { test-with-slope-for-serial-dependent-data }}$

Calvo, J.C., 1986. An evaluation of Thornthwaite's water balance technique in predicting stream runoff in Costa Rica, Hydrological Sciences Journal, 31(1), pp. 51-60, DOI: $10.1080 / 02626668609491027$

Carter, G.A., Otvos, E.G., Anderson, C.P., Funderburk, W.R. and Lucas, K.L., 2018. Catastrophic storm impact and gradual recovery on the Mississippi-Alabama barrier islands, 2005-2010: Changes in vegetated and total land area, and relationships of post-storm ecological communities with surface elevation. Geomorphology, 321, pp. 72-86.

Clemmensen, L.B. and Murray, A., 2006. The termination of the last major phase of aeolian sand movement, coastal dunefields, Denmark. Earth Surface Processes and Landforms, 31(7), pp. 795-808.

Costas, S., Naughton, F., Goble, R. and Renssen, H., 2016. Windiness spells in SW Europe since the last glacial maximum. Earth and Planetary Science Letters, 436, pp. 82-92.

Cowell, R.W., 2008. Coastal Sefton in the prehistoric period. In: J.M. Lewis \& J.E. Stanistreet (eds.) Sand and sea: Sefton's coastal heritage. Archaeology, history and environment 
of a landscape in north west England. pp. 20-27. Sefton Council Leisure Services Department, Bootle.

726

727

728

729

730

731

732

733

734

735

736

737

738

739

740

741

742

743

744

745

746

747

Curreli, A., Wallace, H., Freeman, C., Hollingham, M., Stratford, C., Johnson, H. and Jones, L., 2013. Eco-hydrological requirements of dune slack vegetation and the implications of climate change. Science of the total environment, 443, pp. 910-919.

Dahm, J., Jenks, G. and Bergin, D., 2005. Community-based dune management for the mitigation of coastal hazards and climate change effects: a guide for local authorities. Environment Bay of Plenty.

Darke, I.B., Eamer, J.B.R., Beaugrand, H.E.R. and Walker, I.J., 2013. Monitoring considerations for a dynamic dune restoration project: Pacific Rim National Park Reserve, British Columbia, Canada. Earth Surface Processes and Landforms,38, pp. 983-993

Dezileau, L., Sabatier, P., Blanchemanche, P., Joly, B., Swingedouw, D., Cassou, C., Castaings, J., Martinez, P. and Von Grafenstein, U., 2011. Intense storm activity during the Little Ice Age on the French Mediterranean coast, Palaeogeography, Palaeoclimatology, Palaeoecology, 299(1-2), pp. 289-297, http://dx.doi.org/10.1016/j.palaeo.2010.11.009

Delgado-Fernandez, I. and Davidson-Arnott, R.D.A., 2011. Meso-scale aeolian sediment input to coastal dunes: The nature of aeolian transport events. Geomorphology, 126(1), pp. 217-232.

Dillenburg, S., Hesp, P.A., Barboza, E., Rosa, M.L., Caron, F., Sawakuchi, A. and Forman, S., 2018. Records of Aeolian activity potentially related with the Little Ice Age in Regressive Coastal Barriers of Southern Brazil. International Conference on Aeolian Research (Abstract), 25-29 June, Bordeaux, France 
Douglas, E.M., Vogel, R.M. and Kroll, C.N., 2000. Trends in floods and low flows in the United States: impact of spatial correlation. Journal of Hydrology, 240, pp. 90-105.

El Mrini, A., Anthony, E.J., Maanan, M., Taaouati, M. and Nachite, D., 2012. Beach-dune degradation in a Mediterranean context of strong development pressures, and the missing integrated management perspective. Ocean \& coastal management, 69, pp. 299-306.

Elliott, M., Burdon, D., Hemingway, K.L. and Apitz, S.E., 2007. Estuarine, coastal and marine ecosystem restoration: confusing management and science-a revision of concepts. Estuarine, Coastal and Shelf Science, 74(3), pp. 349-366.

Environmental Systems Research Institute (ESRI), Inc., 2016. How Point Density Works http://desktop.arcgis.com/en/arcmap/10.3/tools/spatial-analyst-toolbox/how-pointdensity-works.htm [Date Accessed 24th August 2018]

Esteves, L.S., Brown, J.M., Williams, J.J. and Lymbery, G., 2012. Quantifying thresholds for significant dune erosion along the Sefton Coast, Northwest England. Geomorphology, 143-144, pp. 52-61

Fenu, G., Cogoni, D., Ulian, T. and Bacchetta, G., 2013. The impact of human trampling on a threatened coastal Mediterranean plant: The case of Anchusa littorea Moris (Boraginaceae). Flora-Morphology, Distribution, Functional Ecology of Plants, 208(2), pp. 104-110.

Galloway, J.N., Townsend, A.R., Erisman, J.W., Bekunda, M., Cai, Z., Freney, J.R., Martinelli, L.A., Seitzinger, S.P. and Sutton, M.A., 2008. Transformation of the Nitrogen cycle: recent trends, questions and potential solutions. Science, 320(5878), pp. 889-892.

García-Romero, L., Delgado-Fernández, I., Hesp, P.A., Hernández-Calvento, L., HernándezCordero, A.I. and Viera-Pérez, M., 2019. Biogeomorphological processes in an arid 

transgressive dunefield as indicators of human impact by urbanization. Science of the Total Environment, 650, pp.73-86.

774 Gilbert, R.O., 1987. Statistical Methods for Environmental Pollution Monitoring, Wiley, NY.

775 Gocic, M. and Trajkovic, S., 2013. Analysis of changes in meteorological variables using Mann-Kendall and Sen's slope estimator statistical tests in Serbia. Global and Planetary Change, 100, pp. 172-182. doi:10.1016/j.gloplacha.2012.10.014

Guo, L., Xiong, S., Wu, J., Ding, Z., Chen, Y., Zhu, L. and Ye, W., 2018. Human activity induced 779 asynchronous dune mobilization in the deserts of NE China during the late Holocene. Aeolian Research, 34, pp. 49-55.

Helsel, D.R. and Hirsch, R.M., 2002. Chapter 12 - Trend Analysis, in Statistical methods in water resources (Vol. 323). Reston, VA: US Geological survey.

Hernández-Cordero, A.I., Hernández-Calvento, L., Pérez-Chacón Espino, E., 2017. Vegetation changes as an indicator of impact from tourist development in an arid transgressive coastal dune field. Land Use Policy, 64: 479-491.

786

Hesp, P.A., 2002. Foredunes and blowouts: initiation, geomorphology and dynamics. Geomorphology, 48(1-3), pp. 245-268.

Hesp, P.A. and Martínez, M.L., 2007. Disturbance processes and dynamics in coastal dunes. In Johnson, A., and Miyanishi, K. (Eds), Plant disturbance ecology. The process and the response. Elsevier. P. 215-247.

Hesp, P.A., Schmutz, P., Martinez, M.M., Driskell, L., Orgera, R., Renken, K., Revelo, N.A.R. and Orocio, O.A.J., 2010. The effect on coastal vegetation of trampling on a parabolic dune. Aeolian Research, 2(2), pp. 105-111.

794 Hesp, P.A., 2013. Conceptual models of the evolution of transgressive dune field systems. Geomorphology, 199, pp. 138-149. 
Hesp, P.A., Hernández-Calvento, L., Hernández-Cordero, A.I. and Gallego Fernández, J.B., 2018. Nebkha or not: the role of rainfall and sediment supply in controlling nebkha vs foredune ridge formation. International Conference on Aeolian Research (Abstract), 25-29 June, Bordeaux, France

Hugenholtz, C.H. and Wolfe, S.A., 2005. Recent stabilization of active sand dunes on the Canadian prairies and relation to recent climate variations. Geomorphology, 68(1-2), pp.131-147. Hughes, L., 2000. Biological consequences of global warming: is the signal already apparent? Trends in Ecology \& Evolution, 15(2), pp. 56-61.

Jackson, D.W.T, and Cooper, J.A.G., 2011. Coastal dune fields in Ireland: rapid regional response to climatic Change, Journal of Coastal Research SI 64, pp. 293-297.

Jackson, N.L. and Nordstrom, K.F., 2011. Aeolian sediment transport and landforms in managed coastal systems: a review. Aeolian research, 3(2), pp. 181-196.

Kamps, P.W.J.T., Nienhuis, P. and Witte, J.P.M., 2008. Effects of climate change on the water table in the coastal dunes of the Amsterdam Water Supply. In Proceedings MODFLOW.

Keenan, T.F., Prentice, I.C., Canadell, J.G., Williams, C.A., Wang, H., Raupach, M. and Collatz, G.J., 2016. Recent pause in the growth rate of atmospheric CO2 due to enhanced terrestrial carbon uptake. Nature Communications, 7, pp. 13428.

Kendall, M. G., Rank Correlation Methods, 4th ed., Charles Griffin: London, 1975.

Konlechner, T., 2018. Post-disturbance evolution of a prograded foredune barrier: the role of wind speed, wind direction and vegetation. International Conference on Aeolian Research (Abstract), 25-29 June, Bordeaux, France.

Lancaster N., 1988. Development of linear dunes in the southwestern Kalahari, southern Africa. Journal of Arid Environments, 14, pp. 233-244. 
820

Lancaster, N. and Helm, P., 2000. A test of a climatic index of dune mobility using measurements from the southwestern United States. Earth Surface Processes and Landforms, 25(2), pp. 197-207.

Lewis, J., 2010. A brief summary of the historical evidence for the weather and climate on the Sefton Coast from the $11^{\text {th }}-20^{\text {th }}$ centuries. University of Liverpool, $63 \mathrm{p}$.

Matthew, S., Davidson-Arnott, R.G.D., Ollerhead, J., 2010. Evolution of a beach-dune system following a catastrophic storm overwash event: Greenwich Dunes, Prince Edward Island, 1936-2005. Canadian Journal of Earth Sciences, 47(3), pp. 273-290.

Mann, H.B., 1945. Nonparametric tests against trend. Econometrica: Journal of the Econometric Society, pp. 245-259.

McDonnell, M.J., 1981. Trampling effects on coastal dune vegetation in the Parker River National Wildlife Refuge, Massachusetts, USA. Biological Conservation, 21(4), pp. 289-301.

McVicar, T.R., Roderick, M.L., Donohue, R.J., Li, L.T., Van Niel, T.G., Thomas, A., Grieser, J., Jhajharia, D., Himri, Y., Mahowald, N.M., Mescherskaya, A.V., Kruger, A.C., Rehman, S. and Dinpashoh, Y., 2012. Global review and synthesis of trends in observed terrestrial near-surface wind speeds: Implications for evaporation. Journal of Hydrology, 416-417, pp. 182-205.

Mendoza-González, G., Martínez, M.L., Rojas-Soto, O.R., Vázquez, G. and GallegoFernández, J.B., 2013. Ecological niche modeling of coastal dune plants and future potential distribution in response to climate change and sea level rise. Global Change Biology, 19(8), pp. 2524-2535.

Miller, T.E., Gornish, E.S. and Buckley, H.L., 2010. Climate and coastal dune vegetation: disturbance, recovery, and succession. Plant ecology, 206(1), p.97. 
844 Miot da Silva, G., Hesp, P., Keim, B., Martinho, C.T. and Ferligoj, Y., 2013. Changes in dunefield geomorphology and vegetation cover as a response to local and regional climate variations. In: Conley, D.C., Masselink, G., Russell, P.E. and O’Hare, T.J. (eds.), Proceedings 12th International Coastal Symposium (Plymouth, England), Journal of Coastal Research, (SI65), pp. 1307-1312, ISSN 0749-0208

Monaghan, G.W., Arbogast, A.F., and Lovis, W.A., 2018. Are Coastal Dune Activation Cycles in the Great Lakes (USA) Linked Across the Northern Hemisphere during the Late Holocene? If so, Why? International Conference on Aeolian Research (Abstract), 2529 June, Bordeaux, France

Moulton, M.A., Hesp, P.A., Miot da Silva, G., Bouchez, C., Lavy, M. and Fernandez, G.B., 2018, Changes in vegetation cover on the Younghusband Peninsula transgressive dunefields (Australia) 1949-2017. Earth Surface Processes and Landforms.

Muhs, D.R., Maat, P.B., 1993. The potential response of eolian sands to Greenhouse Warming and precipitation reduction on the Great Plains of the United States. Journal of Arid Environments, 25, pp. 351-361.

Nordstrom, K.F., Lampe, R. and Vandemark, L.M., 2000. Reestablishing naturally functioning dunes on developed coasts. Environmental Management, 25(1), pp. 37-51.

Pakeman, R.J., Alexander, J., Beaton, J., Brooker, R., Cummins, R., Eastwood, A., Fielding, D., 862 Fisher, J., Gore, S., Hewison, R. and Hooper, R., 2015. Species composition of coastal dune vegetation in Scotland has proved resistant to climate change over a third of a century. Global change biology, 21(10), pp. 3738-3747. Karst Aquifer System. Environmental Processes, pp. 1-27. 
Provoost, S., Jones, M.L.M. and Edmondson, S.E., 2011. Changes in landscape and vegetation of coastal dunes in northwest Europe: a review. Journal of Coastal Conservation. DOI: 10.1007/s11852-009-0068-5.

Psuty, N.P., 1988. Sediment budget and dune/beach interaction. Journal of Coastal Research, (3), pp. 1-4.

872 Pye, K. and Blott, S.J., 2010. Geomorphology of the Sefton Coast sand dunes. In Worsley, A.T., Lymbery, G., Holden, V.J.C., and Newton, M. (Eds) Sefton's Dynamic Coast. Proceedings of the Conference on Coastal Geomorphology, Biogeography and Management, pp. 131-160.

Pye, K., Blott, S.J. and Howe, M.A., 2014. Coastal dune stabilization in Wales and requirements for rejuvenation. Journal of coastal conservation, 18(1), pp. 27-54.

Rhind, P.M., Blackstock, T.H., Hardy, H.S., Jones, R.E. and Sandison, W., 2001. The evolution of Newborough warren dune system with particular reference to the past four decades. In: Houston, J., Edmondson, S.E. Rooney, P. (eds) Coastal dune management, shared experience of European conservation practice. Liverpool University Press, Liverpool, pp. 345-379.

883

Roberts, G., 2014. The lost world of Formby Point: footprints on the prehistoric landscape, $5000 \mathrm{BC}$ to $100 \mathrm{BC}$. Alt Press, Formby.

885

Roca, E. and Villares, M., 2008. Public perceptions for evaluating beach quality in urban and semi-natural environments. Ocean \& Coastal Management, 51(4), pp. 314-329.

887 Ruessink, B.G., Arens, S.M., Kuipers, M. and Donker, J.J.A., 2018. Coastal dune dynamics in 888 response to excavated foredune notches. Aeolian Research, 31, pp. 3-17. 
Seeliger, U., Cordazzo, C.V., Oliveira, C.P. and Seeliger, M., 2000. Long-term changes of coastal foredunes in the southwest Atlantic. Journal of Coastal Research, pp. 10681072.

Smith, P.H., 2009. The sands of time revisited. An introduction to the sand-dunes of the Sefton Coast. Amberley publishing, Stroud, Gloucestershire.

Smith, P.H., 2015. History of human influence on sand stability in the Sefton Coast sanddunes. Unpublished report, $25 \mathrm{pp}$.

Smith, A.B., Jackson, D.W., Cooper, J.A.G. and Hernández-Calvento, L., 2017. Quantifying the role of urbanization on airflow perturbations and dunefield evolution. Earth's Future, 5(5), pp.520-539.

Stephenson, N.L., 1990. Climatic Control of Vegetation Distribution: The Role of the Water Balance. The American Naturalist, 135(5) pp. 649-670.

Su, B.D., Jiang, T. and Jin, W.B., 2006. Recent trends in observed temperature and precipitation extremes in the Yangtze River basin, China. Theoretical and Applied Climatology, 83(1-4), pp. 139-151.

Tabari, H., Marofi, S., Aeini, A., Hosseinzadeh Talaee, P. and Mohammadi, K., 2011b. Trend 905 analysis of reference evapotranspiration in the western half of Iran. Agricultural and Forest Meteorology 151 (2), pp. 128-136.

907 Thornthwaite, C.W. and Mather, J.R., 1957. Instructions and Tables for Computing Potential Evapotranspiration and the Water Balance. Publ. in Climatology, vol.10, no.3, C,W. Thornthwaite \& Associates, Centerton, New Jersey.

910 Thornthwaite, C.W. and Mather, J.R., 1957. Instructions and tables for computing potential evapotranspiration and the water balance (No. 551.57 T515i). Drexel Institute of Technology, Centerton, NJ (EUA). Laboratory of Climatology. 
913 Tsoar, H., 2005. Sand dunes mobility and stability in relation to climate. Physica A: Statistical 914 Mechanics and its Applications, 357(1), pp. 50-56.

915 Tzatzanis, M., Wrbka, T. and Sauberer, N., 2003. Landscape and vegetation responses to 916 human impact in sandy coasts of Western Crete, Greece. Journal for Nature 917 Conservation, 11(3), pp. 187-195.

918 Vautard, R., Cattiaux, J., Yiou, P., Thepaut, J.N. and Ciais, P., 2010. Northern Hemisphere 919 atmospheric stilling partly attributed to an increase in surface roughness. Nature 920 Geosciences, 3(11), pp. 756-761.

921 Wolfe, S.A., 1997. Impact of increased aridity on sand dune activity in the Canadian Prairies. $922 \quad$ Journal of Arid Environments, 36, pp. 421-432.

923 Xu, C., Liu, H., Williams, A.P., Yin, Y. and Wu, X., 2016. Trends toward an earlier peak of the 924 growing season in Northern Hemisphere mid-latitudes. Global Change Biology, 22(8), 925 pp. 2852-2860.

926 Yizhaq, H., Ashkenazy, Y. and Tsoar, H., 2009. Sand dune dynamics and climate change: A 927 modeling approach. Journal of Geophysical Research: Earth Surface, 114(F1).

928 Zhang. X., Vincent, L.A., Hoge, W.D. and Niitsoo, A., 2000. Temperature and precipitation 929 trends in Canada during the 20th century. Atmosphere-Ocean, 38, pp. 395-129 